\title{
Prospects for global market expansion of China's wind turbine manufacturing industry
}

\author{
Jorrit Gosens ${ }^{\mathrm{a}, \mathrm{b}}$, Yonglong Lu $\mathrm{Lu}^{\mathrm{a}, *}$ \\ a State Key Lab of Urban and Regional Ecology, Research Center for Eco-Environmental Sciences, Chinese Academy of Sciences, P.O. Box 2871, \\ Beijing 100085, China \\ ${ }^{\mathrm{b}}$ Graduate University of the Chinese Academy of Sciences, Beijing 100039, China
}

\section{H I G H L I G H T S}

- We assess the pressure to innovate in the Chinese wind turbine market.

- Customer demand is focused more strongly on turbine cost than quality.

- Formalizing connections between users and suppliers reduce pressure to innovate.

- Chinese manufacturers cannot yet compete globally in technological quality.

- Preferential supplies of project finance may provide a vehicle for exports.

\section{A R T I C L E I N F O}

\section{Article history:}

Received 11 November 2013

Received in revised form

22 December 2013

Accepted 23 December 2013

Available online 16 January 2014

Keywords:

Technological innovation system

Wind turbine manufacturing

China

\begin{abstract}
A B S T R A C T
Emerging economies are increasingly contributing to global innovation, including clean-tech innovation. The development of China's wind power sector has often been used to illustrate this point. China's domestic wind power market is the largest in the world and is largely supplied by domestic manufacturers. Competition for market share in the domestic market may pressure firms to innovate, which consecutively improves prospects for global expansion. This paper reviews developments in China's domestic wind turbine market using the Technological Innovation System framework. We analyze the pressure to innovate arising from market competition and assess the prospects for global expansion of Chinese wind turbine manufacturers. We conclude that domestic customers are not pressured or incentivized to perform with respect to power output, such that turbine manufacturers are not pressured to perform with respect to turbine efficiency or maintenance needs. Pressure to innovate is further reduced by formalizing connections between wind farm developers and turbine manufacturers. Chinese turbine manufacturers cannot yet compete with leading global brands in technological leadership. The prospects for exports are improved, however, by the preferential supply of project financing from institutional investors, such as the China Development Bank, from Chinese utilities that seek global expansion and from the manufacturers themselves.
\end{abstract}

(c) 2014 Elsevier Ltd. All rights reserved.

\section{Introduction}

Patterns of global economic development are undergoing change. By 2025, six major emerging economies (Brazil, China, India, Indonesia, the Republic of Korea, and the Russian Federation) will collectively account for more than half of all global growth (World Bank, 2011). Economic growth and technological prowess are known to be strongly interrelated (Abramovitz, 1986; Freeman and Soete, 1997; Kim, 1997; Nelson and Rosenberg, 1993). The changing role of emerging economies in global innovative activity is attracting

\footnotetext{
*Corresponding author. Tel.: +86106 284 9466; fax: +86106 2918177.

E-mail address: yllu@rcees.ac.cn (Y. Lu).
}

increasing academic attention (De Fuentes and Chaminade, 2012; Fu et al., 2011; Lundvall et al., 2009). A number of analysts have focused on the increasing involvement of emerging economies in global clean-tech innovation, including renewable energy technologies (Bayer et al., 2013; e.g., Berkhout et al., 2010; Binz et al., 2012; Levi et al., 2010; Pew Environment Group, 2012; Truffer, 2012).

An example of this trend is the remarkable development of China's wind power sector. In 2000, new Chinese wind power installations totaled $77.3 \mathrm{MW}$, or $2.06 \%$ of global installations (Chinese Wind Energy Association (CWEA), 2012a; Global Wind Energy Council (GWEC), 2012c). In recent years, China's new and cumulative installations of wind power have ranked first globally (Fig. 1). New installations in 2011 stood at $17.6 \mathrm{GW}$, or $43.5 \%$ of the global total (Global Wind Energy Council (GWEC), 2012c). 
China's wind turbine manufacturing has experienced similarly rapid growth. In 2000 , only $2.5 \mathrm{MW}$, or $0.07 \%$ of global installations, was from any of four Chinese manufacturers (Chinese Wind Energy Association (CWEA), 2012a). By 2011, China was home to approximately 80 wind turbine manufacturers, 8 of which were among the global top 15 (Fig. 2). Compared with their foreign counterparts, however, Chinese manufacturers rely on the domestic market to a far larger extent, with very limited exports (Fig. 2).

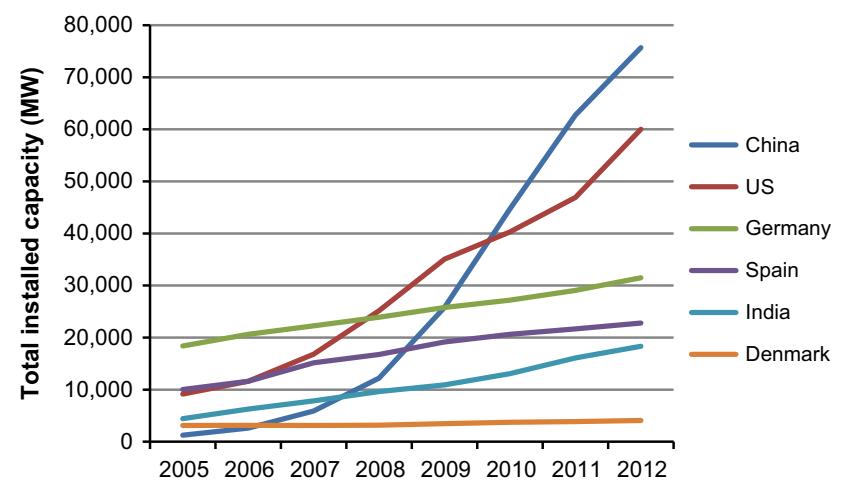

Fig. 1. Global wind power markets.

Notes: includes the top 6 countries by cumulative installments in 2005. Sources: Chinese Wind Energy Association (CWEA) (2013), European Wind Energy Association (EWEA) (2013), Global Wind Energy Council (GWEC) (2012c), Windpower Monthly (2013b).

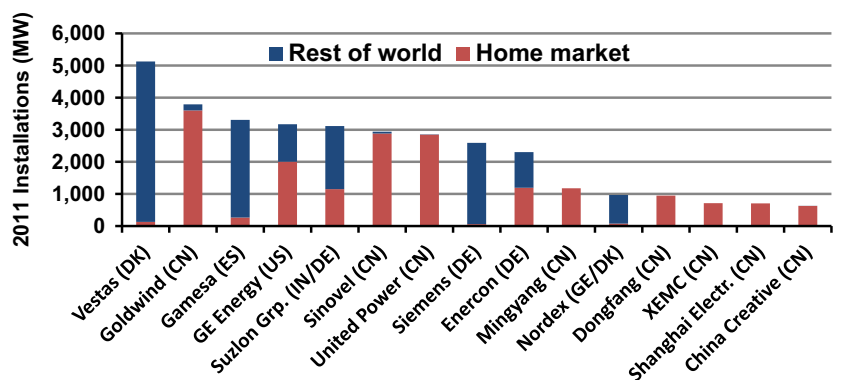

Fig. 2. Global wind turbine manufacturers.

Note: includes the top 15 manufacturers by 2011 market share. Collectively, these accounted for $84.5 \%$ of the 2011 global market. Sources: Chinese Wind Energy Association (CWEA) (2012c), IHS Emerging Energy Research (IHS-EER) (2012).
Further details concerning Chinese and leading global turbine manufacturers are provided in Appendix A.

China's achievements in wind power have been addressed in many earlier publications (e.g., Gosens and Lu, 2013; Han et al., 2009; Kang et al., 2012; Lema and Ruby, 2007; Lema and Lema, 2012; Lewis, 2007; Lewis and Wiser, 2007; Liu and Kokko, 2010; Ru et al., 2012; Wang et al., 2012; Zhang et al., 2013; Zhang and Li, 2012). Largely consistent with China's wind power policies, these papers have recognized China's late-comer status and have focused on processes of technology transfer, learning and capacity building. Policy plans for China's 12th Five-Year Plan period (20112015) appear to seek to end the Chinese wind power sector's dependency on foreign technology and to make China a competitor in global markets. Policy targets include more 'indigenous' innovation, turbine quality levels comparable with the global forefront, and global market expansion (see Table 1).

This paper seeks to contribute to the literature on China's wind power sector by assessing the prospects for global market expansion of China's wind turbine manufacturing. We build on the notion that the nature of competition in the domestic market is a key determinant of innovation and, by extension, prospects for global market expansion (elaborated in Section 2, theory and method). While most of the current literature on wind power in China has adopted a national scope of analysis, we focus on individual manufacturers. We assess their current innovative strength vis-à-vis global leaders, and analyze how current domestic market conditions spur further progress in innovation and prospects for competition in global markets (Section 3). We provide policy recommendations to improve these prospects in Section 4 and concluding remarks in Section 5.

\section{Theory and method}

The domestic market can be instrumental in developing technological leadership and can be a springboard to global markets. Empirically, the global success of wind turbine manufacturers has been found to be correlated to the size of the domestic market (Beise and Rennings, 2005; Lewis and Wiser, 2007). The top 15 manufacturers globally in 2011 (Fig. 2) were from the top 5 countries with the biggest markets and from Denmark (Fig. 1), which has historically been a lead market (Lewis and Wiser, 2007).

The home market can provide a requisite breeding ground for infant industries and can serve as an environment to test and

Table 1

12th Five-Year Plan policies and objectives for China's wind power sector.

12th Five-Year Plan for renewable energy' (National Energy Administration (NEA), 2012)

- By 2015: $100 \mathrm{GW}$ of wind power, $5 \mathrm{GW}$ of which offshore, and $190 \mathrm{TW}$ h production

- By 2020: $200 \mathrm{GW}, 30 \mathrm{GW}$ of which offshore and $390 \mathrm{TW}$ h production

- Focus on wind power bases, seven parks with $10 \mathrm{GW}+$ capacity and offshore parks

- Improve innovative strength and international competition of the domestic industry

- Improve the servicing industry, wind power standards and wind power use efficiency

- Encourage more distributed wind power utilization to relieve grid stress

‘Opinions on deepening technological system reform and accelerating the construction of a national innovation system’ (2012-2020) (State Council of P.R. China, 2012)

- Focus on seven 'strategic emerging industries,' including wind power

- Improve 'indigenous' and independent innovative capacity; master key technologies with control over key IPR

- Formation of a number of industry giants with international influence and a batch of creative SMEs

- Integration of domestic education and science complex with the industrial chain

- Expansion of domestic and foreign markets

‘12th Five-Year Plan: special plan for the development of wind power science and technology' (2012-2015) (MOST, 2012a)

- Shift from quantity to quality; reach international levels in turbine performance and reliability

- Master the design, production, and operation of 3- to 5-MW direct-drive turbines and 7-MW turbines and components

- Master the development, design and batch production of very large (10 MW+) offshore turbines 
Table 2

Functions of a technological innovation system.

Source: based on Bergek et al. (2008), Hekkert et al. (2007).

\begin{tabular}{|c|c|}
\hline System function & Refers to \\
\hline 1. Knowledge development & $\begin{array}{l}\text { - Patenting and scientific publishing } \\
\text { - R\&D phase funding and activity }\end{array}$ \\
\hline 2. Knowledge diffusion & $\begin{array}{l}\text { - Knowledge exchange in networks } \\
\text { - Trade and co-development of IPR }\end{array}$ \\
\hline 3. Guidance of the search & $\begin{array}{l}\text { - Steering development toward specific technological alternatives } \\
\text { - Articulation of interest by leading consumers } \\
\text { - Regulatory pressure (e.g., quotas for renewable energy) }\end{array}$ \\
\hline 4. Entrepreneurial activities & $\begin{array}{l}\text { - New entrants in the market } \\
\text { - Diversification of activities of incumbents } \\
\text { - Amount and variety of experiments with the technology }\end{array}$ \\
\hline 5. Market formation & $\begin{array}{l}\text { - Sizes and types of markets formed } \\
\text { - Drivers of market formation (e.g., support scheme) }\end{array}$ \\
\hline 6. Resource mobilization & $\begin{array}{l}\text { - Availability of capital } \\
\text { - Availability and quality of human resources } \\
\text { - Complementary resources }\end{array}$ \\
\hline 7. Creation of legitimacy & $\begin{array}{l}\text { - Stakeholder attitudes and recognition of (societal) benefits of the technology } \\
\text { - Rise and growth of interest groups and lobbying } \\
\text { - Political debate in parliament and media }\end{array}$ \\
\hline
\end{tabular}

develop new technologies and products (Beise, 2005; Fagerberg, 1995; Porter, 1990). Competition for market share in the home market pressures manufacturers to innovate, which improves their prospects for global expansion (ibid). The relative size of the domestic market matters because it determines the possible extent of revenue and therefore the possible extent of investment in R\&D (Beise, 2005).

A relatively large domestic market is, however, not a sufficient precondition for global technological leadership and export success. Porter (1990) and Fagerberg (1995) have suggested that the pressure to innovate stems from 'advanced domestic users' (for wind turbine manufacturers, the users would be wind farm developers). They noted that innovation may be induced by demand conditions, i.e., when domestic users sufficiently scrutinize the technological quality of different (turbine) suppliers and select their supplier accordingly (Fagerberg, 1995; Porter, 1990). Inducing turbine manufacturers to innovate does require that 'rivalry is sufficient to respond to [demand conditions]' (Porter, 1990: p. 72). Market entry by foreign manufacturers can also have a beneficial effect on this rivalry (Faber and Hesen, 2004; Porter, 1990; Scott, 1997), although the benefits of protectionist measures for infant industries in emerging economies are still being debated (confer e.g., Fu et al., 2011; Kim, 1993; Lewis and Wiser, 2007). Fagerberg (1995: p. 247) further extended the rivalry argument to product users, arguing that 'users that are under continuous pressure to improve their performance are more likely [...] to demand improvements from their suppliers'. A last prerequisite for the utility of the home market as a springboard to global markets is that product qualities demanded in the domestic market should be similar to those demanded in the global market (Beise, 2005; Johanson and Vahle, 1977).

Innovation does not depend solely on interaction between users and producers, however. For instance, for clean-tech innovation in particular, government support plays an important role, e.g., in the provision of research funding, the creation of fiscal incentives for the utilization of sustainable technological alternatives, and the design of technological roadmaps. The development of a technological field can be assessed using the 'Technological Innovation
Systems' (TIS) framework (Bergek et al., 2008; Hekkert et al., 2007). Clean-tech innovation has received considerable attention in the TIS literature, with a particular focus on renewable energy (Markard et al., 2012). One of the attractive features of the TIS literature is the clarity of analytical scope it offers, through a list of 'system functions,' i.e., processes required to spur innovation (Table 2). The inclusion of basic research activities, government support measures, entrepreneurial activities and market formation suits the scope of our assessment.

The data collection for this assessment was accomplished in two separate steps. We first performed a round of desk research, reviewing journal articles, official statistics, reports from industry associations, research organizations, etc., and news items from newspapers, government and company websites. This information was used to draw up a sketch overview of China's wind power TIS formation. We then interviewed 18 experts to correct or verify and enrich our preliminary results. The experts were 4 representatives of Chinese turbine manufacturers, 2 representatives of foreign manufacturers, 5 market analysts, 5 academics and 2 government officials.

\section{China's wind turbine sector: Market mechanisms, innovation and export market prospects}

In Sections 3.1-3.7, we assess the TIS surrounding China's wind turbine manufacturers, structured according to TIS functions (Table 2).

\subsection{Knowledge development}

The development of new knowledge is central to the functioning of innovation systems (Hekkert et al., 2007). We can use patenting activity to assess innovativeness in a certain technological field or country (Bergek et al., 2008). On the national level, Chinese activity in renewable power technologies has risen sharply in recent years (Bayer et al., 2013). In 2011, global wind power patent applications by applicants from China totaled 2600, compared to 3044 for EU-15 applicants and 1234 for US applicants 


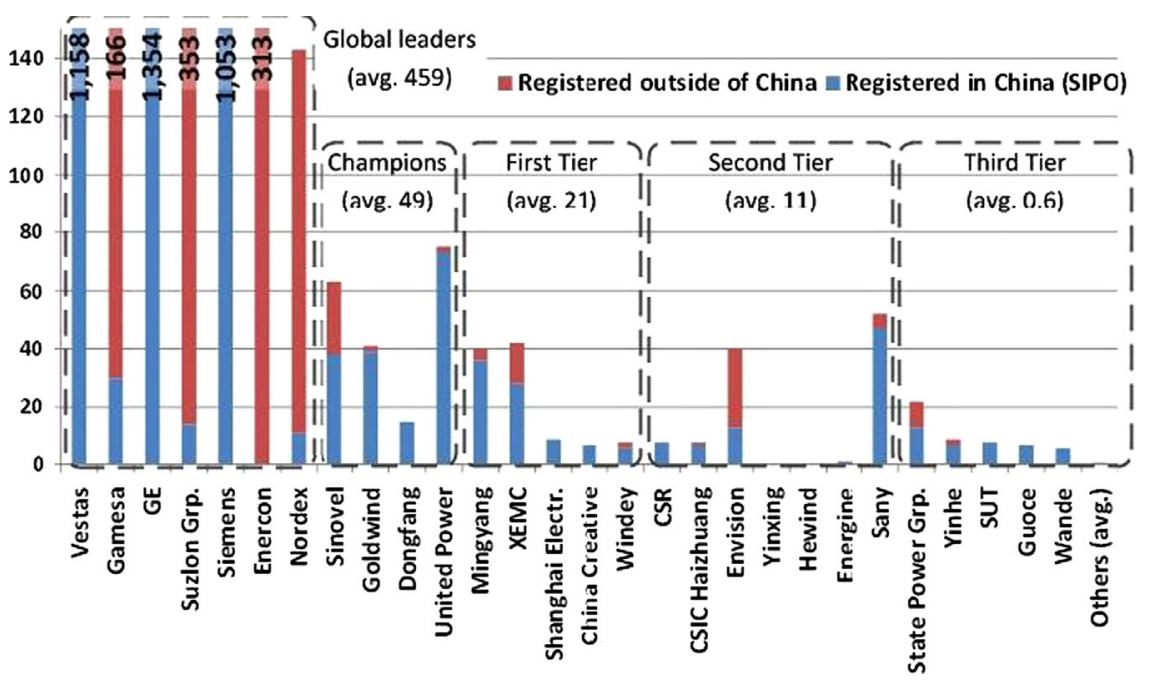

Fig. 3. Patent applications by wind turbine manufacturers (totals for 2010-2012).

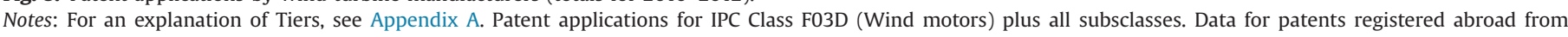

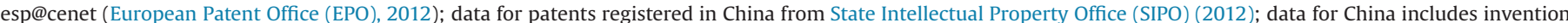

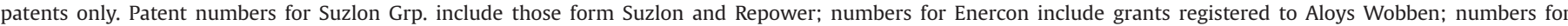
Goldwind includes patent applications to subsidiary Vensys, numbers for XEMC includes applications by subsidiary Darwind. 'Others (avg.)' includes 49 more firms.

(analysis of online databases from European Patent Office (EPO) (2012), State Intellectual Property Office (SIPO) (2012).

The Chinese patent numbers may be inflated, however, because China's patent office (SIPO) has three different types of patents (invention, utility model and design patents), with only the first of the three being comparable in its rigor with respect to novelty assessment. Between 2010 and 2012, 52\% of all wind patents ${ }^{1}$ registered at SIPO were invention patents. China recently amended its patent law to require absolute global novelty (as opposed to being required only for those not yet registered in China). This amendment only went into effect for new applications in early 2010 (State Council of P.R. China, 2010). Furthermore, patenting costs are relatively low in China, compared to those in the EU or the US (Roland Berger Market Research, 2004; Sayre, 2010). Lastly, a number of interviewees argued that Chinese patent numbers are inflated because political goals for innovation include grant numbers as evaluation criteria for personnel in both government and private research institutes. These interviewees argued that a relatively low share of patents granted would actually be utilized in commercial applications. This last observation is supported by the number of patent applications by Chinese wind turbine manufacturers, which is far less than the numbers of applications by their global counterparts (Fig. 3).

Conversely, a number of leading global turbine manufacturers have utilized patent portfolios to ensure thorough protection from cross-filing and to induce competitors to license from them (Totaro and Associates, 2011; UNEP/ICTSD/EPO, 2010). Application numbers may further be inflated by filing in multiple countries. For instance, between 2010 and 2012, Vestas, Siemens and GE filed 192, 388 and 197 applications, respectively, with State Intellectual Property Office (SIPO) (2012). These applications were previously or simultaneously filed with other patent offices. Lastly, Chinese manufacturers have often used foreign technology licenses, which likely include restrictions on patentability (more in Section 3.2).

Among Chinese manufacturers, patent activity largely corresponds to sales volume (see Appendix A for details). Sany and Envision are the only firms that really stand out. Sany is China's largest heavy machinery and power generation equipment manufacturing

${ }^{1}$ The numbers here refer to the IPC patent class F03D (wind motors), plus subclasses. conglomerate. As such, it has plenty of experience in related engineering fields and plenty of resources to spend on R\&D activity. Envision has, unlike most manufacturers, started operations based on an independently developed turbine design. It has R\&D centers in Denmark, China, Japan and the US, as well as collaboration centers at a number of Chinese universities. Both Sany and Envision are recent market entrants, however, and neither has been able to benefit much from recent market growth. The Institute of Wind Energy at the Shenyang University of Technology (SUT) is considered one of China's knowledge suppliers (see also Section 3.2), but the Institute applied for only 8 (invention) patents between 2010 and 2012.

State support for basic R\&D is arranged via the creation of 'State Key Laboratories' and grants for government research programs. The establishment of a State Key Laboratory ensures state funding for an undetermined period of time, subject to annual evaluation. Some Key Laboratories have research themes, e.g., offshore wind power. State Key Laboratories are usually established within universities or within the Chinese Academy of Sciences. In the wind power sector, State Key Laboratories have mostly been established at manufacturers' facilities, as manufacturers are expected to be better able to commercialize products than academic institutions (UNIDO, 2010). Currently, wind power related State Key Laboratories are established at Sinovel, Goldwind, United Power, XEMC and Windey, and SUT. Annually renewed research programs that include wind power are the National High-tech R\&D program ('863') and the National S\&T support program. Grants from the 2012 ' 863 ' and S\&T support programs were awarded to Sinovel, Goldwind, United Power and Windey (MOST, 2012b, 2012c). Although other manufacturers will receive $R \& D$ funding from provincial or local level governments, state support is directed nearly entirely toward the national leaders in the field.

\subsection{Knowledge diffusion}

The innovative capacity of manufacturers from late-comer countries can be assessed in terms of the relative dependence on foreign technology. The use of a technology license indicates relatively weak in-house capacities for turbine design, whereas cooperative and independent development indicate increasing technological competence (Lema and Lema, 2012; Lewis, 2007; Lewis and Wiser, 2007). 
Table 3

Technological mechanisms for turbine development of Chinese manufacturers.

\begin{tabular}{|c|c|c|c|c|}
\hline & Name & License & Cooperative development & Independent development \\
\hline Champions & $\begin{array}{l}\text { Sinovel } \\
\text { Goldwind } \\
\text { Dongfang } \\
\text { United Power }\end{array}$ & $\begin{array}{l}2005 \text { (Fuhrlander) } \\
1998 \text { (Jacobs) } \\
2004 \text { (RePower) }\end{array}$ & $\begin{array}{l}2007 \text { (Windtec) } \\
2010 \text { (Windtec) } \\
2007 \text { (Aerodyn) }\end{array}$ & $\begin{array}{l}2009 \\
2008 \text { (Vensys) } \\
2012\end{array}$ \\
\hline First Tier & $\begin{array}{l}\text { Mingyang } \\
\text { XEMC } \\
\text { Shanghai Electric } \\
\text { China Creative } \\
\text { Windey }\end{array}$ & $\begin{array}{l}2006 \text { (Aerodyn) } \\
2006 \text { (Zephyros) } \\
2006 \text { (DeWind) } \\
2001 \text { (RePower) }\end{array}$ & $\begin{array}{l}2010 \text { (Aerodyn) } \\
2009 \text { (Aerodyn) } \\
2006 \text { (RePower) }\end{array}$ & $\begin{array}{l}2009 \text { (Darwind) } \\
2010 \\
2006 \\
2009\end{array}$ \\
\hline Second Tier & $\begin{array}{l}\text { CSR } \\
\text { CSIC Haizhuang } \\
\text { Envision } \\
\text { Yinxing } \\
\text { HEwind } \\
\text { Energine } \\
\text { Sany }\end{array}$ & $\begin{array}{l}2006 \text { (Frisia) } \\
2007 \text { (Mitsubishi) } \\
2005 \text { (Goldwind) } \\
2005 \text { (Acciona) }\end{array}$ & $\begin{array}{l}2010 \text { (Windtec) } \\
2010 \text { (Aerodyn) } \\
2007 \text { (Aerodyn) } \\
2008 \text { (SUT) }\end{array}$ & $\begin{array}{l}2008 \\
2011 \\
2009\end{array}$ \\
\hline Third Tier & $\begin{array}{l}18 \text { Firms } \\
4 \text { Firms } \\
32 \text { Firms }\end{array}$ & Various & Various & \\
\hline
\end{tabular}

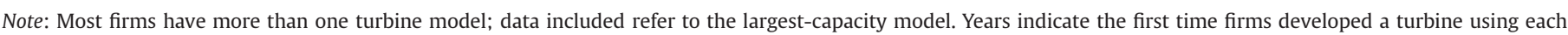

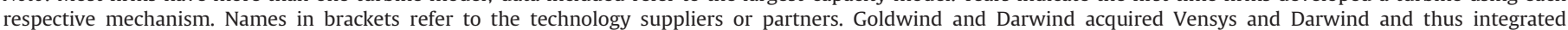

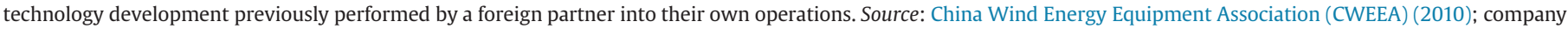
websites.

The Chinese government began encouraging international technology transfer to the domestic wind industry soon after it installed the first utility-scale wind turbines. China's earliest manufacturers were two joint ventures between foreign and domestic manufacturers, created as part of a government program (the 'Ride the Wind' program of 1997) (State Planning Commision (SPC), 1997). Between 2003 and 2009, technology transfer was promoted by making wind farm development permits conditional on a minimum percentage of locally manufactured content (NDRC, 2003, 2009a). As recently as the period between 2006 and 2011, a number of manufacturers received financial assistance from the Global Environment Fund and the NDRC to develop multi-MW wind turbines, in cooperation with foreign technology partners (under the China 'Renewable Energy Scale-up Program'; CRESP, 2012). (For a more elaborate discussion of technology transfer efforts in the Chinese wind sector see, e.g., Gosens and Lu (2013), Lema and Lema (2012), Lewis (2012), Ru et al. (2012). The current policy focus is on domestic development and control over key technology (see Table 1 ).

On a global level, Chinese manufacturers have entered the industry relatively late. Goldwind, Windey and Dongfang were the only currently active Chinese manufacturers that were engaged in wind turbine manufacturing before 2005.

Virtually without exception, Chinese wind turbine manufacturers started operations with a licensing deal or partnership with an experienced foreign turbine designer. The evolution of the mechanisms used for turbine design by Chinese manufacturers is presented in Table 3. Many Chinese manufacturers, particularly the 'Champions' ${ }^{2}$ and 'First Tier' ${ }^{2}$ firms, have recently started to develop turbines independently. Although quite a few 'Third Tier' firms claim that they are engaged in independent development of wind turbine designs, our interviewees were skeptical of these claims. They argued that most of these firms assemble rather than manufacture turbines. The interviewees considered claimed independent designs to mostly be guides to assembling components

\footnotetext{
${ }^{2}$ For explanation of the Tier system that we use to categorize manufacturers, see Appendix A.
}

sourced from suppliers. This view is consistent with the near-total absence of patent applications by Third Tier firms.

There are also a number of manufacturers that use licenses from domestic suppliers, particularly from the Wind Energy Technology Institute of SUT. At least 17 Third Tier firms work on the basis of a technology license from SUT (China Wind Energy Equipment Association (CWEEA), 2010). Only three firms (Sany, New United and Sharpower), however, have managed to put designs into production (Chinese Wind Energy Association (CWEA), 2012a; China Wind Energy Equipment Association (CWEEA), 2010). China Creative is a spin-off firm of SUT. HEwinds' company website states it manufactures its $600-\mathrm{kW}$ and $750-\mathrm{kW}$ under a license from Goldwind. An engineer at SUT who was interviewed for this research indicated that SUT had no license arrangements with any foreign customers nor any current expectations of such arrangements. As far as we are aware, no Chinese manufacturer has managed to license its technology to a foreign partner.

\subsection{Guidance of the search}

Globally, two technological developments are being pursued. First, there is a long-standing trend toward turbine capacity increases. Several-hundred-kW turbines were the state of the art in the early nineties, MW-sized turbines emerged in the late nineties, and multi-MW turbines have been available since the turn of the millennium (Ackermann and Söder, 2002). Larger turbines are more efficient (they extract more energy from the same wind resources) and have lower installation and maintenance costs (in comparison to several smaller turbines), although they are more challenging to engineer European Wind Energy Association (EWEA) (2011b). A second trend is that of the search for offshore turbine models. Offshore wind farms may utilize potentially better wind resources at sea and may be built closer to load centers, i.e., urban centers in coastal areas. The search for offshore models is linked with the search for unit-scale increases. High-capacity turbines are more economical in challenging installation conditions, such as offshore locations.

The global leaders in wind turbine technology all developed multi-MW turbines during the first half of last decade and are 


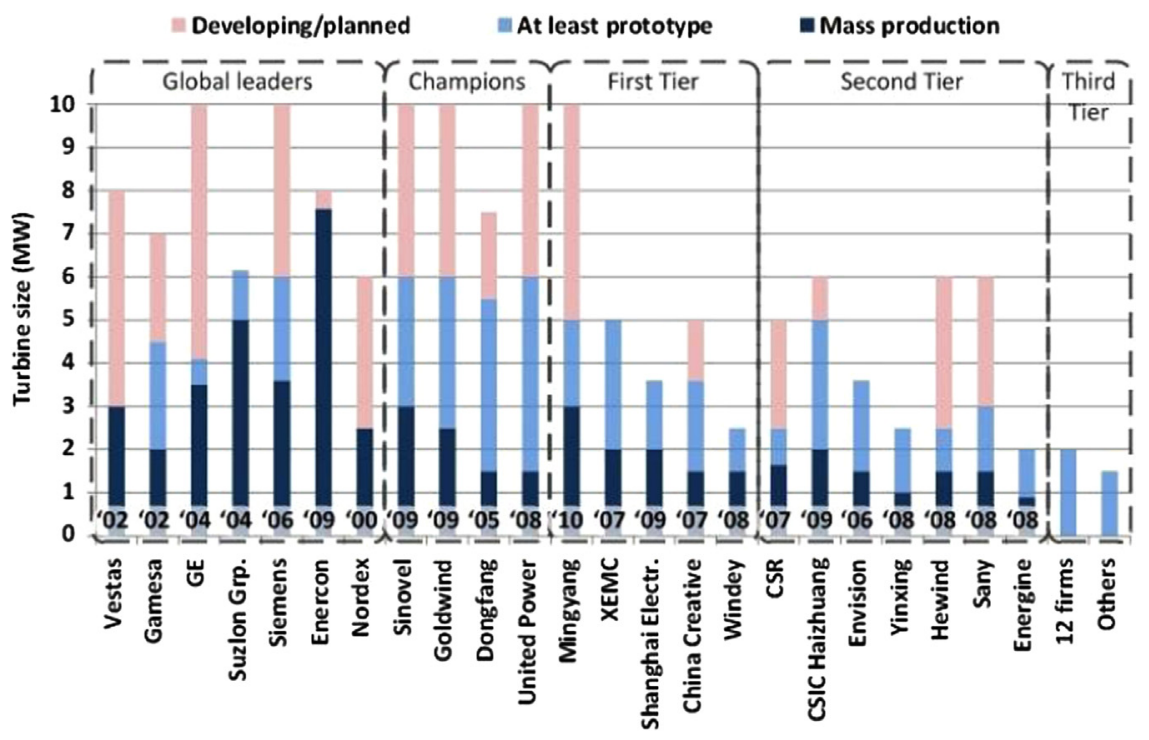

Fig. 4. Development of turbines offered by different manufacturers.

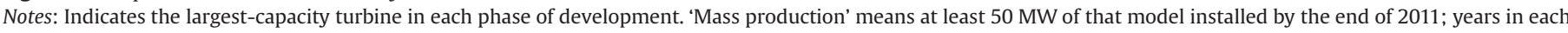

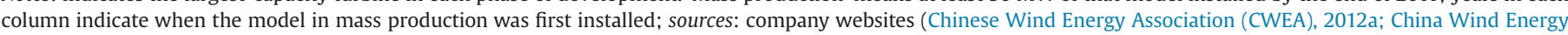
Equipment Association (CWEEA), 2010).

working on further scale increases, especially for the offshore market segment (Fig. 4). Chinese manufacturers have long trailed this development but are catching up fast. By the end of 2008, only one Chinese manufacturer (XEMC) had installed turbines larger than 1.5 MW (Chinese Wind Energy Association (CWEA), 2012a). Since then, manufacturers across the board have developed turbines approximately $3 \mathrm{MW}$, and many are developing turbines with capacities of approximately $5 \mathrm{MW}$, comparable to or larger than those manufactured by the global leaders (Fig. 4). These are all prototypes, however; some of these have units installed at test farms, while others have only recently rolled of the production line (company websites; Chinese Wind Energy Association (CWEA), 2012a). Four Chinese manufacturers have even announced that they are developing 10-MW offshore models (Fig. 4).

Our interviewees were skeptical about the market demand for machines of such large capacities in the near future, however. They mentioned three main issues:

1. Lower costs of lower-capacity turbines:

The bulk of current installations in China are turbines of approximately $1.5 \mathrm{MW}$, with only $1.9 \%$ of installations having unit capacities of $2.5 \mathrm{MW}$ or more (cumulative, 2011). The average turbine size in China remains smaller than in the US and EU markets (Fig. 5). The annual reports of manufacturers indicate that orders for turbines of up to $3 \mathrm{MW}$ are gaining pace, but this is not the case for their largest turbines (Table 4). Interviewees assessed the preference for coupling lowercapacity turbines with their lower cost, i.e., two 1.5-MW turbines cost less than one 3-MW turbine.

2. Skepticism about performance of very-high-capacity turbines: The market analysts that we interviewed expressed the view that the development of 10-MW turbines stems largely from a political push to demonstrate China's technological prowess (defined in MOST (2012a)); see also Table 1). Previously, China's largest wind farm developer (Longyuan) criticized the push for an offshore wind farm with domestically manufactured 3-MW units, as a showcase for the Shanghai expo. The criticism was that Sinovel, which supplied the turbines for the project, had overestimated its technological capabilities and took too little time to develop and test the new turbine, resulting in poor operational performance (People's Daily, 2011). The combined

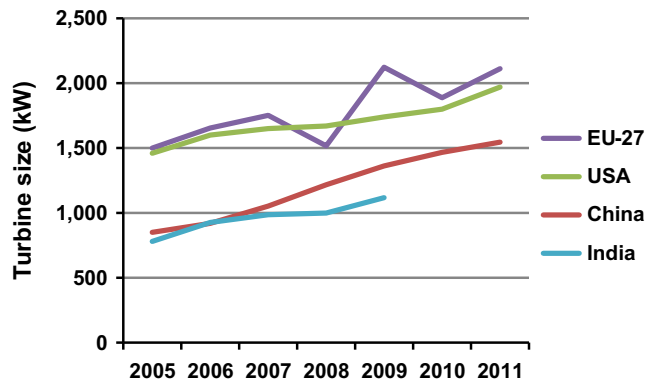

Fig. 5. Average turbine size, key global markets.

Notes: Turbine size of new installed capacity in that year. Sources: Chinese Wind Energy Association (CWEA) (2013), European Wind Energy Association (EWEA) (2011a, 2012c), Wiser and Bolinger (2012).

Table 4

Order backlog for key Chinese manufacturers of high-capacity turbines. Source: company annual reports. Note that order backlogs are not necessarily firm and unconditional orders.

\begin{tabular}{lrrrrrll}
\hline Manufacturer & \multicolumn{2}{l}{ Order backlog (nr. of turbines) } & \multicolumn{2}{l}{$\begin{array}{l}\text { Avg. size } \\
\text { (MW) }\end{array}$} \\
\cline { 2 - 7 } & $1.5 \mathrm{MW}$ & $2 \mathrm{MW}$ & $2.5 \mathrm{MW}$ & $3 \mathrm{MW}$ & $5 \mathrm{MW}$ & $6 \mathrm{MW}$ & \\
\hline Sinovel & 2415 & 0 & 0 & 422 & 1 & 0 & 1.72 \\
Goldwind & 2575 & 0 & 384 & 5 & 0 & 0 & 1.63 \\
Mingyang & 1136 & 123 & 0 & 67 & 0 & 1 & 1.63 \\
\hline
\end{tabular}

effect of lower cost and lower risk associated with lowercapacity turbines is reflected in manufacturers' current order backlogs (Table 4 ).

3. Slow offshore developments:

Very large turbines are particularly well suited to offshore wind farms. Chinese offshore installations stood at $403 \mathrm{MW}$ at the end of 2012 (Chinese Wind Energy Association (CWEA), 2013), whereas those in Europe were $4.3 \mathrm{GW}$ (in mid 2012), with another $3.7 \mathrm{GW}$ under construction (European Wind Energy Association (EWEA), 2012a). China's offshore wind farms use turbines from Siemens (50 MW), Sinovel (170 MW), and Goldwind $(110 \mathrm{MW})$. The remainder are prototype turbines from CSIC, Shanghai Electric, United Power, XEMC, Mingyang, Sany and Envision (Chinese Wind Energy Association (CWEA), 2013). 
Although China's recent 12th Five-Year Plan for renewable energy stipulates ambitious goals of $5 \mathrm{GW}$ of offshore installations by 2015 and $30 \mathrm{GW}$ by 2020, developments have lagged behind schedule (National Energy Administration (NEA), 2012). Although tenders in 2010 and 2011 resulted in development permits being awarded for offshore projects, discussion on the siting of offshore farms among different government agencies has seriously delayed progress (Energy Research Institute (ERI), 2012).

The relative lack of demand for Chinese-brand high-capacity and offshore turbines reduces testing opportunities, stalling their further development and the build-up of operational history.

\subsection{Entrepreneurial activities}

Fast growing demand for wind turbines has attracted many new entrants to the domestic manufacturing industry, growing from 6 firms in 2005 to 68 in 2010 (Fig. 6). The State Council warned of an overheating industry in State Council of P.R. China (2009). Installations in 2011 totaled $17.6 \mathrm{GW}$, while production capacity exceeded $30 \mathrm{GW}$ (Chinese Wind Energy Association (CWEA), 2012b, 2013). Installations in 2012 totaled $12.96 \mathrm{GW}$ (Chinese Wind Energy Association (CWEA), 2013), while production capacity climbed to $37 \mathrm{GW}$ or more (BTM Consult, 2012). This growth in capacity was due in part to the sheer number of manufacturers, but the problem was exacerbated by the

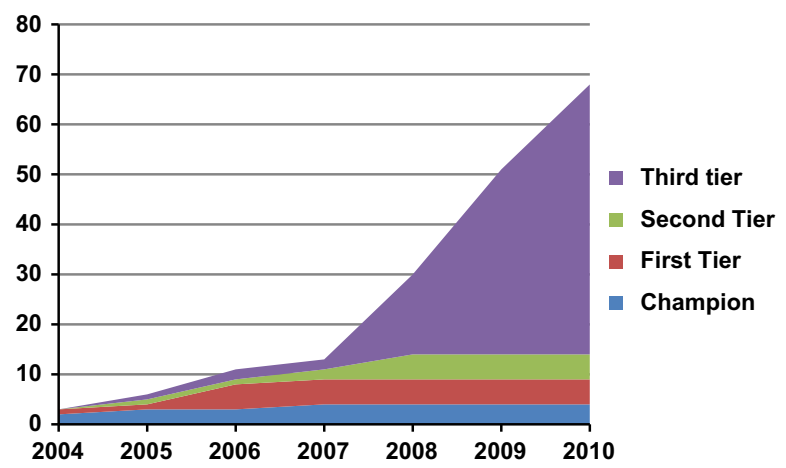

Fig. 6. Date of entry of manufacturers.

Note: Source: China Wind Energy Equipment Association (CWEEA) (2010), company wesbites). increasingly large sizes of the wind farms being developed (more in Section 3.5). To compete for equipment tenders that come in batches of several GW simultaneously, firms need to have sufficient manufacturing capacity available. Furthermore, some local and provincial governments have introduced 'localization rates,' awarding projects to manufacturers on the precondition that they set up manufacturing capacity for local employment (Chinese Wind Energy Association (CWEA), 2012b).

The customer base for turbine manufacturers, i.e., the wind farm developers, has also changed considerably in recent years. Historically, the most important developer has been Longyuan. This state-owned enterprise (SOE) was established in 1993 with a mission to develop renewable energy. In 2002, Longyuan was incorporated as a subsidiary of Guodian, one of the so-called 'Big 5' power companies (the others being China Power Investment (CPI), Datang, Huadian and Huaneng). These are state-owned enterprises (SOE) under the control of the central government. NDRC (2007) mulled a Renewable Portfolio Standard (RPS) of 3\% of non-large hydro renewables in generation capacity by 2010 and $8 \%$ by 2020 for power companies with more than $5 \mathrm{GW}$ of total capacity. The 'Big 5' have since led investment in wind farm development (Fig. 7). Collectively, they operate $58 \%$ of China's wind farms (as of the end of 2011). Other SOEs, mostly utilities under central or provincial government control, operate the remaining further $32 \%$ (Fig. 7).

A recent trend in entrepreneurial activity is that of increasingly formal connections between wind farm developers and turbine manufacturers (Table 5). This trend may help reduce investment costs for wind farm developers (Accenture, 2012). However, this trend also reduces competition, as a connection with a turbine manufacturer will also make it the preferred turbine supplier. Collectively, developers with formal connections with turbine manufacturers controlled 59.5\% of the turbine market (for new installations as of 2011) (Table 5).

The most relevant example is the connection between Longyuan and United Power, which are both subsidiaries of the Guodian Group. United Power was established in 2007 but was the 2nd biggest manufacturer in 2012 (Chinese Wind Energy Association (CWEA), 2013). The success of this connection has depended nearly exclusively on sales to Longyuan and Guodian (Table 5). In 2009, Longyuan started preparations for future off-shore development with a 32-MW intertidal test farm in Rudong, Jiangsu Province, installing 16 turbines from 8 different manufacturers (Envision, Goldwind, Mingyang, SANY, Sinovel,

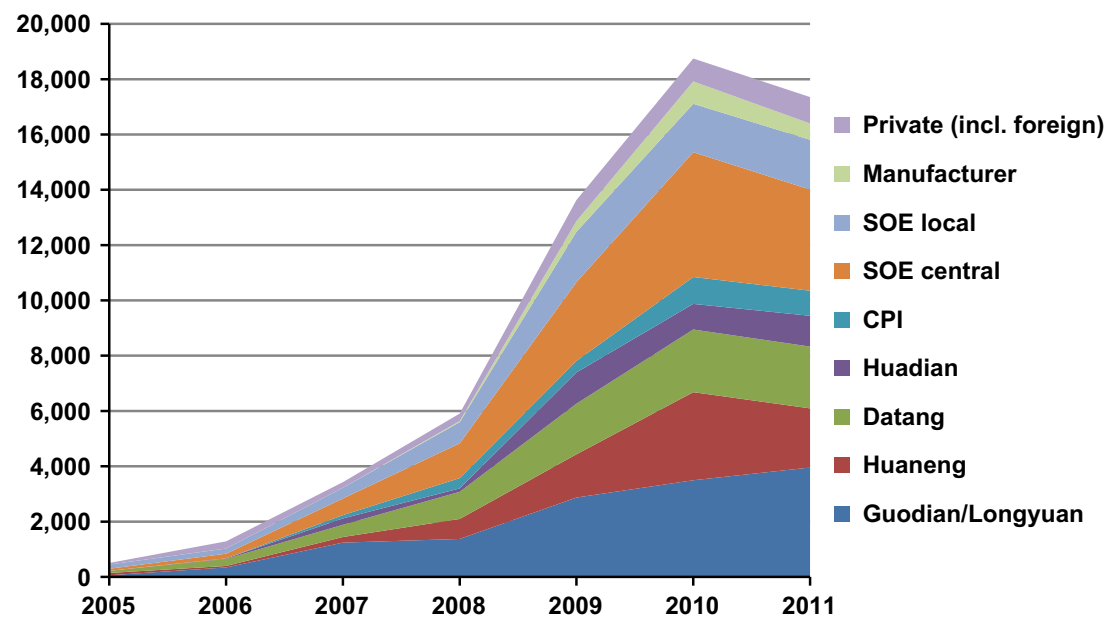

Fig. 7. China's wind farm developers by annually installed capacity (MW).

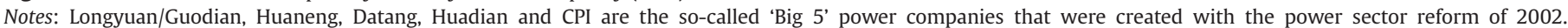
'Manufacturer' refers to turbine manufacturers that have invested in wind farm development. Source: Chinese Wind Energy Association (CWEA) (2012a). 
Table 5

Formalizing relationships between wind farm developers and turbine manufacturers.

Sources: Chinese Wind Energy Association (CWEA) (2012a) and sources mentioned in the table text.

\begin{tabular}{|c|c|c|c|c|c|}
\hline \multirow[t]{2}{*}{ Developer } & \multicolumn{2}{|c|}{$\begin{array}{l}\text { Wind farms in operation } \\
\text { (year end 2011) }\end{array}$} & \multirow[t]{2}{*}{ Turbine manufacturer } & \multirow[t]{2}{*}{ Type of connection } & \multirow[t]{2}{*}{ Since } \\
\hline & MW & $\%$ Of dom. Market & & & \\
\hline Longyuan & 9716 & $15.6 \%$ & United power & Both subsidiaries of Guodian Corp. & 2007 \\
\hline
\end{tabular}

- Longyuan became a subsidiary of Guodian in 2002 (see text in Section 3.4); United Power was established as a subsidiary of Guodian in 2007

- 39\% of Longyuan's 2011 installations were with United Power turbines, almost three times as much as the next largest supplier

\begin{tabular}{|c|c|}
\hline Guodian & 3887 \\
\hline
\end{tabular}

- Guodian relied on Longyuan for wind power development until 2007. Interviewees indicated that Guodian started to develop wind farms itself, in part because of reluctance by Longyuan to use a larger proportion of United Power turbines than it already does

- 76\% of Guodian's cumulative installations (as of the end 2011) were with United Power turbines. 89\% of United Power's cumulative sales have been to Longyuan and Guodian

Huaneng

7964

$12.8 \%$

Sinovel

'Good relations'

2005

- A company spokesperson explained Sinovel's success with Huaneng as being due to 'good relations,' although no formal connections, e.g. in ownership, could be identified. A number of interviewees spoke of rumors of future formalization of connections between Sinovel and Huaneng, without indicating what form such a formalization might take, e.g., a joint venture or takeover

- Huaneng has purchased three times more turbines from Sinovel than from any other manufacturer and is Sinovel's largest customer. Huaneng has also been the top customer for Sinovel's 3-MW model (ibid) and is currently in negotiations concerning an offshore project using 17 units of Sinovel's 6-MW turbine (Xinhua News, 2012 a)

Huaneng

7964

$12.8 \%$

Mingyang

Joint venture

Aug. 2012

- The joint venture is for the development of wind farms domestically and overseas (company website)

- Nearly 40\% of Mingyang's 2011 sales were to Huaneng
Datang
7937
$12.7 \%$
China creative
Majority shareholder
Aug. 2011

- Datang has a 70\% stake in China Creative (State Owned Assets Supervision and Administration Comission (SASAC), 2011)

- 43\% of China Creative's 2011 sales were to Datang

$\begin{array}{llll}\text { Datang } & 7937 & 12.7 \% & \text { XEMC }\end{array}$

2006

- XEMC's wind branch is invested in by Datang (30\%) and XEMC (70\%) (company website)

- $45 \%$ of XEMC's cumulative sales (as of the end of 2011) were to Datang
China Guangdong
2911
$4.7 \%$
Mingyang
Joint Venture
Sep. 2011

Nuclear

- The companies, both from Guangdong Province, established a joint venture focusing on offshore and overseas developments (company website)

- As of the end of 2011, China Guangdong Nuclear had not installed any turbines from Mingyang

$\begin{array}{llll}\text { Tianrun } & 1349 & 2.2 \% & \text { Goldwind }\end{array}$

- Tianrun is a subsidiary of Goldwind and exclusively uses Goldwind turbines
Three Gorges
1092
$1.7 \%$
Goldwind
Shareholder
Unclear

Corporation

- The Three Gorges Corporation holds 31\% of Goldwind's shares (company annual report)

- $68 \%$ of all Three Gorges Corp. installations are with Goldwind turbines

Ningxia electric

1073

$1.7 \%$

Ningxia Yinxing

Full subsidiary

2007

- All of Yinxing's sales have been to the Ningxia Electric Group.

Ningxia electric

1073

$1.7 \%$

Nordex-Yinchuan

Joint venture

2006

- Nordex-Yinchuan is a joint venture between Nordex and a subsidiary of the Ningxia Electric Group. (company website)

- $47 \%$ of Nordex-Yinchuan's sales have been to the Ningxia Electric Group

CECEP

895

$1.4 \%$

Windey

Majority shareholder

2006

- The China Energy Conservation and Environmental Protection Group (CECEP; previously CECIC) purchased a controlling share in Windey

MOFCOM (Zhejiang Province) (2006)

- 39\% of CECEP cumulative installations (as of the end of 2011) were with Windey turbines 
Table 5 (continued)

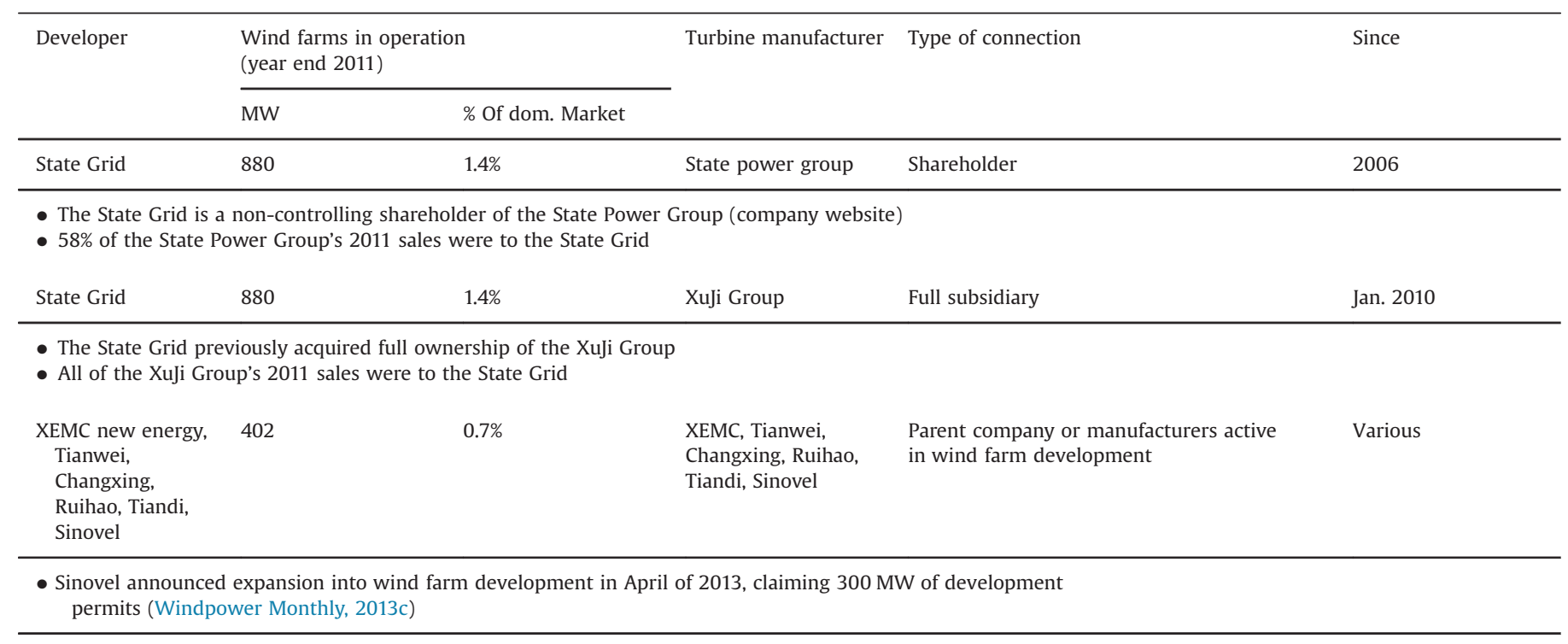

Shanghai Electric and United Power) (Chinese Wind Energy Association (CWEA), 2013). It remains to be seen whether the operational performance of these different turbines will affect Longyuan's future choice of off-shore turbine supplier or whether its connections with United Power will overrule such considerations.

It should be noted that most of these formal relationships have been formed relatively recently. Their impact on competition, i.e., to what extent developers will use exclusive suppliers, remains to be seen.

\subsection{Market formation}

\subsubsection{Chinese and global market growth}

Annual installations in China peaked at $18.9 \mathrm{GW}$ in 2010 but were down to $17.6 \mathrm{GW}$ in 2011 and $12.96 \mathrm{GW}$ in 2012 (Chinese Wind Energy Association (CWEA), 2012b). Forecasts predict 12 to $15 \mathrm{GW}$ of installations annually until 2015 and 18 to $20 \mathrm{GW}$ from then until 2020 (overview of forecasts from CWEA, GWEC, CREIA and BTM, as reported in Chinese Wind Energy Association (CWEA), 2012a). The recent slowdown was largely due to stricter control over permitting by the central government. Permit authority for wind farms up to $50 \mathrm{MW}$ used to be in the hands of provincial governments. Most of China's wind farms have been developed in 49.5-MW sections to avoid the slower permitting procedures of the central authorities. This has, among other things, complicated the planning of additional grid capacity and high levels of curtailment (Li et al., 2012; Zhao et al., 2012a). China introduced national feed-in tariffs (FIT) in mid-2009 and concurrently stipulated that newly planned wind farms were eligible to receive FIT premiums only after approval by the central government's NDRC (2009b). China's latest policy targets are $100 \mathrm{GW}$ by 2015 and 200 GW by 2020 (National Energy Administration (NEA), 2012). China is currently the largest global market and is expected to remain so for the foreseeable future (Fig. 8).

The European and US markets make up the bulk of the remainder of the global market, but there is uncertainty concerning their forecasted growth. Throughout 2012, it remained unclear whether US financial support for wind power ('production tax credits' or PTC) would be extended. The EIA has predicted 2013 installations to slump to 1 to $2 \mathrm{GW}$ as a result, down from $13.1 \mathrm{GW}$ in US Energy Information Administration (EIA) (2012). In early 2013, the US Congress finally agreed to extend the PTC for 2013 but without longer-term guarantees (effects of this policy

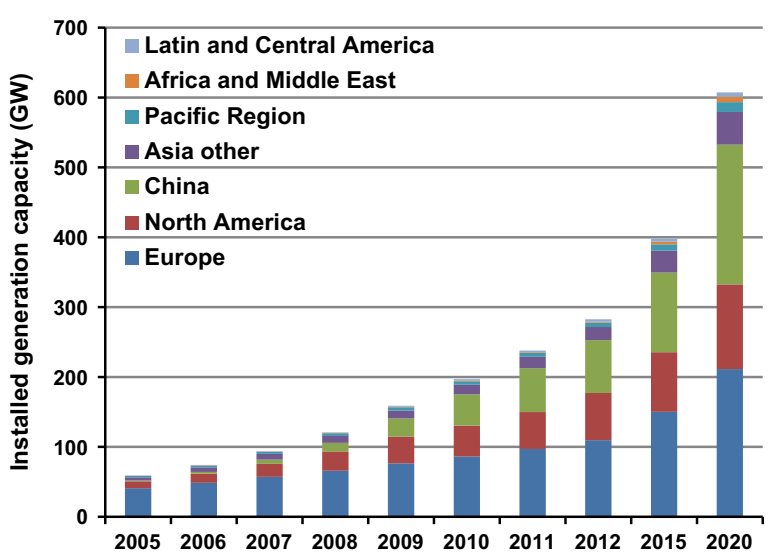

Fig. 8. Global wind turbine installations, historical and forecast for 2015 and 2020. Notes: Sources: Global Wind Energy Council (GWEC) (2012b, 2012c); country grouping as in Global Wind Energy Council (GWEC) (2012b); 2020 forecast for China set at 200 GW, as targeted by National Energy Administration (NEA) (2012) and in line with forecasts from Chinese Wind Energy Association (CWEA) (2012b).

uncertainty are discussed in e.g., Barradale, 2010). The European market is slowing down due to record low carbon prices, which have reduced the incentive to invest in wind power (@REF). Austerity has had an effect on renewable energy support in Spain, Portugal and Italy in particular and in a number of the earlier growth markets (European Wind Energy Association (EWEA), 2012b; Global Wind Energy Council (GWEC), 2012b). India, included in 'Asia other' in Fig. 8, is another important growth market but remains behind China in scale. Other emerging markets in South America, Southeast Asia and Africa are expected to grow at a rate of approximately $5 \mathrm{GW}$ annually up to 2015 (Global Wind Energy Council (GWEC), 2012b).

\subsubsection{Differences between domestic and export markets}

The Chinese market differs from the most important export markets in terms of three basic characteristics:

1. Lower average turbine size:

As elaborated in Section 3.3. 
2. Much lower turbine prices:

Prices paid for turbines in the Chinese market have consistently been much lower than those in the countries with advanced markets (Fig. 9). Chinese manufacturers have been able to offer turbines at lower prices than their foreign competitors, even if these competitors have manufacturing plants within China (Lewis, 2012; Fig. 9), largely due to the localization of component manufacture. Historically, many components needed to be imported, but the supply chain in China is increasingly able to satisfy local demand, with the exception of the demand for highly specialized steel components used in axle and yaw bearings (Chinese Wind Energy Association (CWEA), 2012b; Han et al., 2009). Our interviewees indicated that there is a gap in quality between Chinese component manufacturers and the global leaders but that this difference is offset by a far larger price gap. Manufacturing overcapacity (see Section 3.4) has further contributed to price competition. Overcapacity, both in turbines and in component manufacture, is concentrated in the 1.5-MW class. Our interviewees further indicated that development costs have traditionally been very low, as the designs used had been acquired through licensing (see Section 3.2). Newer models are increasingly developed in house, which interviewees indicated will increase $R \& D$ expenditures and reduce cost differences between Chinese and foreign brands.

3. Far higher market share of Chinese turbine brands:

The domestic market is almost entirely claimed by domestic brands. Since approximately 2005, Chinese turbine brands have

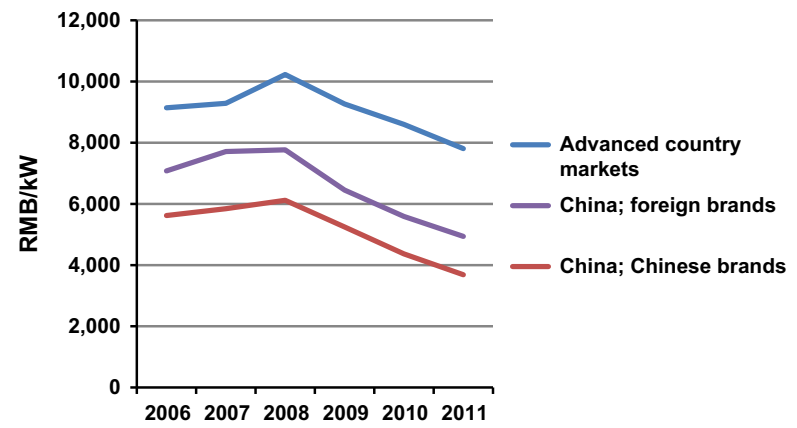

Fig. 9. Turbine prices in China and advanced country markets.

Notes: 'Advanced country markets' is the average for the US, Denmark, Germany and Spain (weighted by market size). Sources: combination of European Wind Energy Association (EWEA) (2011a), IEA Wind (2012), Lewis (2012), 2011 update from CWEA. pushed out foreign competitors (Fig. 10). The four 'National Champions' have led this trend, claiming $65.5 \%$ of the domestic market in 2010. Supply has diversified since then, in favor of First Tier firms in particular, while foreign brands have seen their market shares continue to drop. The near exclusive control of the domestic market contrasts with the very limited Chinese presence in other markets (Table 6), although a number of manufacturers are negotiating foreign projects (Chinese Wind Energy Association (CWEA), 2012a, 2012b).

\subsubsection{Differences between domestic and export market demand}

The preference for smaller, lower-cost, and Chinese-brand turbines in the domestic market is attributable to the following six characteristics of market demand:

1. Policy targets focused on installed capacity, not power generation:

Table 6

Overview of Chinese wind turbine exports (MW).

\begin{tabular}{|c|c|c|c|c|}
\hline Manufacturer & 2009 & 2010 & 2011 & 2012 \\
\hline \multicolumn{5}{|l|}{ National champions } \\
\hline Goldwind & 4.5 & \multirow[t]{4}{*}{4.5} & 189 & 87.25 \\
\hline Sinovel & 15 & & & \multirow[t]{3}{*}{177} \\
\hline Dongfang & & & & \\
\hline United Power & & & 9 & \\
\hline \multicolumn{5}{|l|}{ First Tier } \\
\hline Mingyang & & \multirow[t]{5}{*}{1.5} & & 49.5 \\
\hline XEMC & & & 5 & 4 \\
\hline Shanghai electr. & 6.25 & & & \\
\hline Creative & & & & 61.2 \\
\hline Windey & & & & 1.5 \\
\hline \multicolumn{5}{|l|}{ Second Tier } \\
\hline CSIC & & \multirow{3}{*}{4.5} & 4 & \\
\hline HEWind & & & 2 & \\
\hline SANY & & & 12 & 50 \\
\hline \multicolumn{5}{|l|}{ Third Tier } \\
\hline New United & 3 & 3 & & \\
\hline A-Power & & 2.05 & & \\
\hline Total & 28.75 & 15.55 & 221 & 430.45 \\
\hline As \% of global market (excl. China) & 0.12 & 0.08 & 0.97 & 1.35 \\
\hline As \% of Chinese brand sales & 0.24 & 0.09 & 1.38 & 3.41 \\
\hline
\end{tabular}

Notes: no exports occurred before 2008; sources Chinese Wind Energy Association (CWEA) (2012c, 2013), Global Wind Energy Council (GWEC) (2012c).

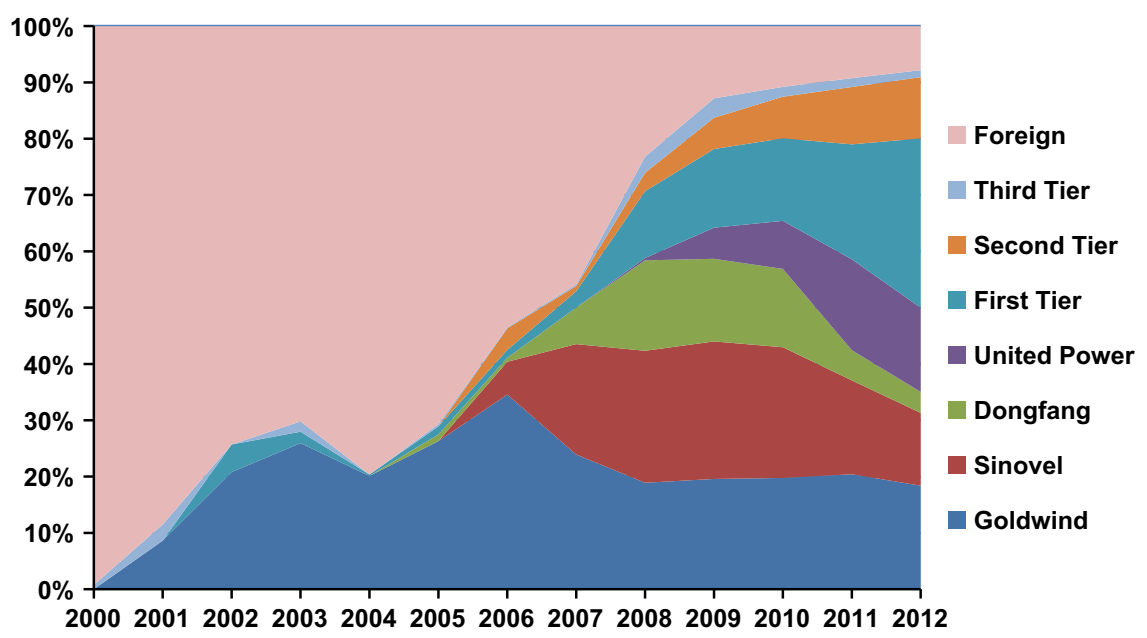

Fig. 10. Turbine manufacturers' share of the Chinese market.

Notes: share of annual market share. Source: Chinese Wind Energy Association (CWEA) (2012a), with 2012 update for top 20 manufacturers). 
China has attempted to ensure fulfillment of national policy ambitions for renewable power with obligatory Renewable Portfolio Standards (RPS) (Table 7; see also Section 3.4). These RPSs are set in percentages of generation capacity, not power production. Effectively, an RPS can be fulfilled by the installation of a number of wind turbines, regardless of the amount of electricity they deliver to the grid. Recently, production-based quotas have been discussed (Table 7). The proposed quotas would require provincial governments to issue electric power development plans that also ensure minimum consumption levels of renewables (Fig. 11). The plan appears to be aimed at relieving grid stress by fixing imbalances in wind power production (concentrated in the north) and power consumption (concentrated in coastal provinces) (for more on grid issues, see e.g., Li et al. (2012), Zhao et al. (2012a)).

The proposal initially also included $\mathrm{kW}$ h-based quotas for both power and grid companies, but these have since been abandoned (Table 7). A number of our interviewees indicated that both power and grid companies have influential lobbies and would be reluctant to accept targets that could incur high costs. This reluctance is exacerbated by the interdependency of power and grid companies in meeting such targets.

2. Rush to obtain land with prime wind resources:

Developing a wind farm requires a development permit and a lease for the land (under Chinese property law, all land belongs to the State). Leases for industrial purposes last for 50 years, but development permits typically require the developer to construct a farm within two years or lose the development rights. To safeguard their long-term renewable energy strategies, power companies are competing to secure sufficient land with prime wind resources. One interviewee referred to the phenomenon as a 'land grab.' He explained that developers were reluctant to invest in turbines with longer life spans and higher power output because such investments would reduce available funds

Table 7

China's renewable power production and consumption targets.

Renewable portfolio standard (2007)

- Power companies with more than 5 GW of generation capacity are obligated to have 3\% of generation capacity from non-hydro renewables by 2010 and $8 \%$ by 2020

- Legal basis: Medium- and long-term renewable energy development plan (NDRC, 2007)

Renewable power quota (draft of 2012)

- Power production or consumption quota of non-hydro renewables for power companies, grid companies and provinces. The 2015 targets are the following

- Power companies with more than $5 \mathrm{GW}$ of generation capacity should generate $6.5 \%$ of all power from renewables

- Grid companies should purchase certain minimum amounts of power from renewable sources; quotas are $15 \%$ for the Inner Mongolia Grid Company, $10 \%$ for the Shaanxi Grid Company, 5\% for the State Grid, and 3.2\% for the Southern Power Grid Company

- Provincial governments should ensure certain minimum amounts of consumption of renewable power within their provinces; see Fig. 11 for details.

- Legal basis: Renewable power quota regulation (draft) (CEC, 2012)

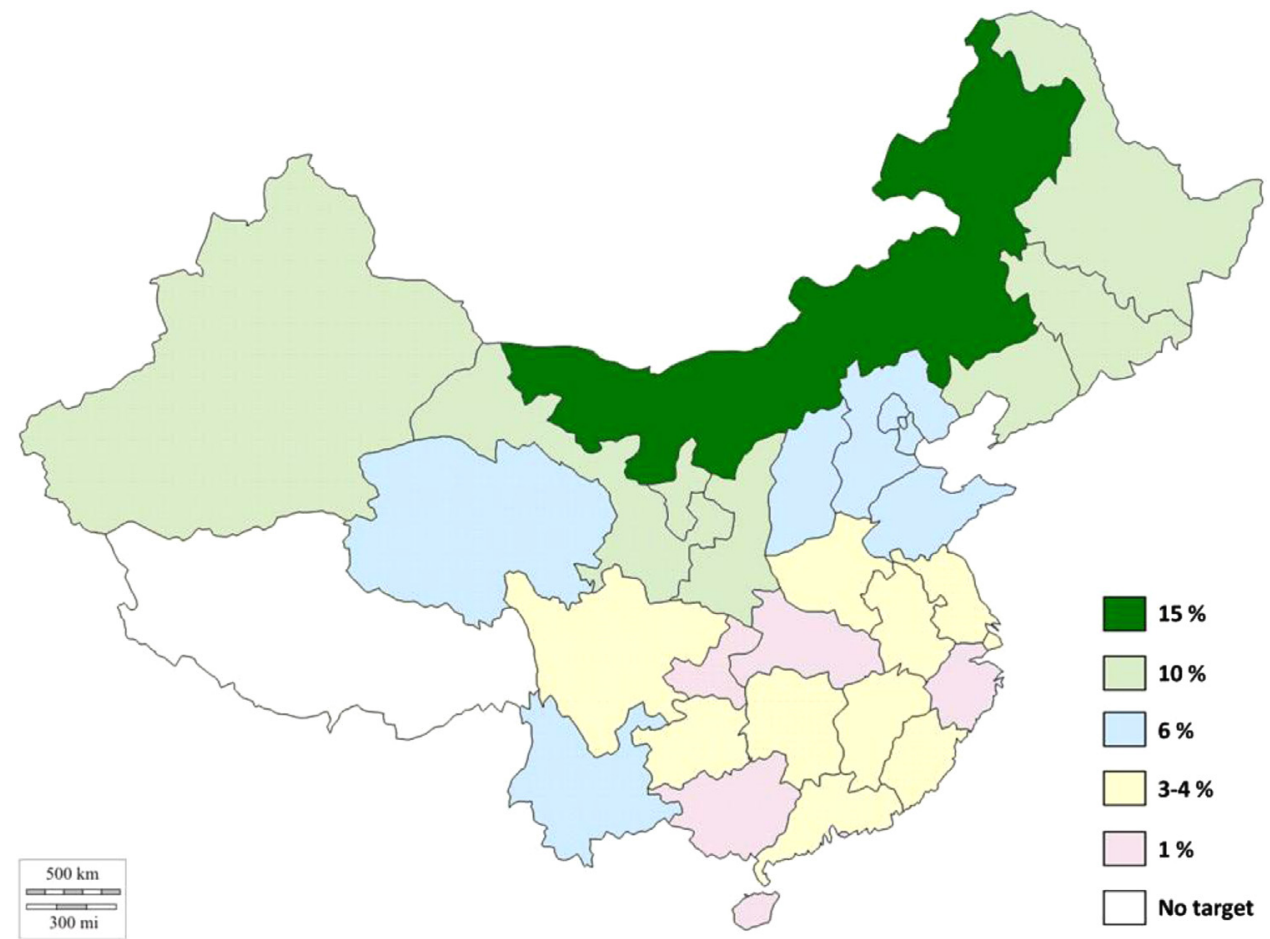

Fig. 11. Provincial level renewable power consumption quota.

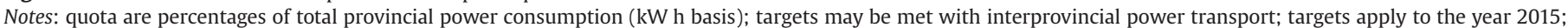
source: CEC (2012). 
for more top-quality plots of land. The financial benefits of being able to exploit these resources for the next 50 years outweigh the downside of using shorter-lived, less productive turbines for the first 10 to 20 years.

3. Concessions and 'concentrated equipment tenders':

A portion of China's wind farm development permits are auctioned in concession tenders organized by the central government.

In five annual rounds (2003-2007), a total of $2.6 \mathrm{GW}$ of permits were awarded to the developer that asked for the lowest power price premium (Global Wind Energy Council (GWEC), 2007). Individual permits were for several $100 \mathrm{MW}$. Developers, incentivized by, amongst other things, RPS obligations, were eager to obtain these rights. Competitive bidding resulted in irrationally low bids, with the price pressure subsequently transferred to turbine suppliers, who were eager to receive the large orders (Li et al., 2010; Liu and Kokko, 2010). The concession tender mechanism was abandoned with the introduction of nationally determined feed-in tariffs (FIT) of between 510 and 610 RMB/MW h in 2009 (details in Hu et al. (2013), NDRC (2009b).

The policy push to reduce the cost of wind power development continued, however, in so-called 'concentrated equipment tenders' for China's wind bases. These bases are a total of eight regions that will develop $10+\mathrm{GW}$ of wind power each (Chinese Wind Energy Association (CWEA), 2012b). The tendering process for these bases is overseen by the central government's NDRC, with separate tenders for developers and equipment manufacturers. Developers are then obligated to use the turbines of the winning equipment tender bidder. Interviewees indicated that apart from minimal technical requirements to participate in the tender (e.g., a unit capacity of at least $1.5 \mathrm{MW}$ and a minimum of $100 \mathrm{MW}$ of previous installations with the turbine model offered), the only selection criterion in these tenders was the price per kilowatt. Three tenders totaling 12.6 GW were held between 2008 and 2010 (Fig. 12). The National Champions have won the bulk of the tenders, as their scale of operations made it possible for them to bid lower prices for these large orders.

With a combined capacity of $15.2 \mathrm{GW}$ of the total of $75.7 \mathrm{GW}$ of installations by the end of 2012, these concessions and concentrated equipment tenders will certainly have an impact on the industry. Although these mechanisms have not been used for onshore developments since 2010, offshore development permits have been awarded in concessions, and again, developers have outbid each other to unprofitable levels. The bids were 680 to $780 \mathrm{RMB} / \mathrm{MW} \mathrm{h}$, while installations costs at sea may be two to three times higher (IEA/ERI, 2012).

4. SOEs dominate wind farm development:

The state-owned utilities dominate wind power development (Fig. 7). These SOEs have an incentive to actively participate in achieving policy goals, i.e., to develop wind farms but also use domestic manufacture. There is no concrete obligation for the procurement of domestic wind power equipment, but there is a clear political desire to nurture the domestic wind turbine industry (see, e.g., the policies in Table 1). SOE management teams are evaluated on the basis of their adherence to government objectives, with possible consequences for their future careers (Li et al., 2008; Xu, 2011). Furthermore, such efforts will increase the enterprises' political clout in lobbying (e.g., for power pricing policies) and permit procedures for thermal power projects, which remain their main sources of income.

5. Short operational history instills little confidence in quality claims:

The most holistic metric for comparing different turbines is their so-called 'levelized cost of electricity' (LCOE). Turbine qualities that affect the LCOE include the turbine cost, efficiency (the amount of power generated in local wind conditions), maintenance cost, foregone revenue in turbine downtime, and turbine lifetime. Of these qualities, only turbine cost can be established with certainty. This is particularly true for turbines from Chinese manufacturers, most of which have been active only since 2005 or later. Manufacturers' claims concerning expected efficiency, downtime, maintenance needs and lifetime are, therefore, relatively unsupported by operational data. This is true to a greater extent for higher-capacity and offshore models, which have only been developed very recently (see Section 3.3). Faced with a 'blind spot' in decision making, developers have tended to focus on the only certain variable, i.e., turbine cost.

6. Curtailment reduces the incentive for high-quality turbines: The pace of wind farm development and the reluctance of power grid companies to invest in grid connections have led to long connection delays. By the end of 2011, the installed capacity was $62.4 \mathrm{GW}$ (Chinese Wind Energy Association (CWEA), 2012b), but the total connected and operating capacity was only $45 \mathrm{GW}$ (Shi, 2012), meaning that $28 \%$ stood idle and was not generating revenue.

Power companies have also been unable or unwilling to purchase power generated by wind farms and have complained about the intermittency of the wind power supply and the concentration of power generation in regions with relatively low power demand (for details see e.g., Yang et al. (2012b), Zhao et al. (2012b). Surplus power supply gets curtailed, i.e., wind farms get disconnected from the grid. In 2011, curtailment of wind power reached $17 \%$ nationwide and $23 \%$ in regions with high concentrations of wind farms (Chinese Wind Energy Association (CWEA), 2012b), and the curtailment only worsened in 2012 (Table 8). The uncertainty concerning the ability to sell power that has been generated reduces the incentive to pay premium prices for turbines with very high efficiencies or low amounts of downtime.
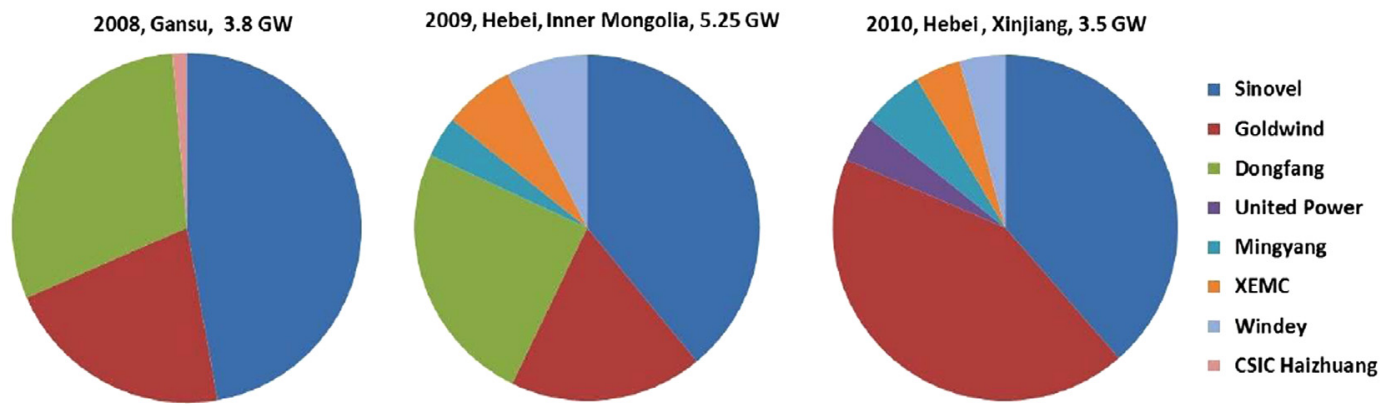

Fig. 12. Outcome of wind base 'concentrated equipment tenders'.

Source: collected news items from China Wind Power Net (2013), Chinese Wind Energy Association (CWEA) (2012a). 
3.5.4. Competitive pressure and innovation in the domestic market

The competitive pressure in China's turbine market is strongly oriented toward the price per kilowatt. The senior management of Sany has criticized China's system for equipment tenders, stating that qualities such as power output, maintenance needs and operational safety have become secondary concerns (Wu and $\mathrm{Li}$, 2012). This has also slashed profit margins and resulted in neglect of $R \& D$ for product development ( $\mathrm{Wu}$ and $\mathrm{Li}, 2012$ ). The same line of argument was reiterated by the top management of Goldwind, Sinovel and United Power at a conference forum for turbine manufacturers (CWP 2012 Conference, 2012b). Financial data for turbine manufacturers corroborate this argument (Table 9). Note that the slowdown in global markets has had similar effects on global leaders (Table 9). The consecutive pressure on R\&D budgets is also apparent in manufacturers' annual reports. Goldwind (2012) planned R\&D expenses for 2011 were cut by 59\% to reduce operating expenses. Similarly, Sinovel scrapped recruitment plans for 350 new employees, mostly R\&D personnel (Xinhua News, 2012b).

\subsection{Resource mobilization}

In the domestic market, Chinese turbine manufacturers and wind farms developers have had easy access to financing as a result of government stimulus measures adopted in response to the global financial crisis. In fact, loans may have been available too easily, leading to 'blind and duplicative investment' and, consequently, manufacturing overcapacity (State Council of P.R. China, 2009). Power companies used to have plenty of capital available, but this too has changed in recent years. Coal prices have risen, while electricity prices remain fixed at low, government-

Table 8

Wind power production and curtailment in China.

Sources: combination of CEC (2013), Shi (2012), Windpower Monthly (2013a).

\begin{tabular}{lllll}
\hline $\begin{array}{l}\text { Total production } \\
(\mathrm{TW} \text { h) }\end{array}$ & $\begin{array}{l}\text { Curtailment } \\
(\mathrm{TW} \text { h) }\end{array}$ & $\begin{array}{l}\text { Curtailment } \\
(\%)\end{array}$ & $\begin{array}{l}\text { Foregone revenue } \\
\text { (billion RMB) }\end{array}$ \\
\hline 2011 & 72.3 & 12.3 & 16.8 & 6.6 \\
2012 & 100.4 & 20 & 19.9 & 10 \\
\hline
\end{tabular}

determined levels (Yang et al., 2012a). The weaker financial performance of the utilities' core businesses may now hamper wind farm investment (Global Wind Energy Council (GWEC), 2012a).

Access to financing has been more difficult in export markets. Due diligence by foreign financiers requires sufficient information on operational performance. A number of international project managers of Chinese manufacturers who we interviewed indicated that the operational history of turbines in China was not considered in the due diligence for projects in the EU or US. This was said to be true even for turbine models based on licenses from globally recognized designs (e.g., those listed in Table 3). There was also a perceived investment risk due to the lack of independent performance auditing in China. Lastly, the manufacturers' poor financial performance in recent years has further increased investment risk. Turbine sales include long warranty and maintenance contracts, and uncertainty over firm survival increases doubts concerning the fulfillment of such contract obligations (CWP 2012 Conference, 2012a).

Specific difficulties exist for Sinovel, which is being sued by AMSC, which claims that Sinovel infringed on its intellectual property rights (IPR) with respect to its control system software (AMSC, 2011). Foreign developers are wary about being included in legal disputes when using Sinovel turbines. Brazilian developer Desenvix agreed to buy Sinovel's turbines only after sufficient proof that the turbines included components and software acquired from different sources (Financial Times, 2012). Irelandbased Mainstream Renewable Power withdrew from a memorandum of understanding (MoU) with Sinovel to develop $1 \mathrm{GW}$ of wind parks in Ireland as a result of the dispute (company website, Recharge News, 2012).

Foreign projects may also be co-financed by the China Development Bank (CDB), which is tasked with assisting Chinese firms' foreign expansion. The CDB has, among other things, extended credit lines of $\$ 6$ bn to Goldwind, $\$ 5$ bn to United Power/Longyuan to develop wind farms in Pakistan, and $\$ 3$ bn to the Beijing Construction Engineering Group to develop a wind farm in Argentina using Chinese turbines (Bloomberg, 2012a, company websites). The inclusion of financing at low interest rates increases the competitiveness of turbine manufacturers. This is particularly true in markets in which financing is less readily accessible, such as emerging economies in Latin America, Southeast Asia and Africa

Table 9

Financial performance of wind turbine manufacturers, 2010-2012.

\begin{tabular}{|c|c|c|c|c|c|c|c|c|c|}
\hline & \multicolumn{3}{|c|}{ Sales $^{\mathrm{a}}(\mathrm{MW})$} & \multicolumn{3}{|c|}{ Revenue $^{\mathrm{b}}$ (mln RMB) } & \multicolumn{3}{|c|}{ Profit $^{\mathrm{c}}$ (mln RMB) } \\
\hline & 2010 & 2011 & 2012 & 2010 & 2011 & 2012 & 2010 & 2011 & 2012 \\
\hline \multicolumn{10}{|c|}{ Chinese firms } \\
\hline Goldwind & 4007 & 3105 & 2583 & 17,475 & 12,756 & 11,224 & 2799 & 864 & 207 \\
\hline Sinovel & 4386 & 2939 & 1947 & 20,325 & 10,436 & 4000 & 3133 & 529 & -582 \\
\hline Mingyang & 1203 & 1470 & 804 & 5518 & 5516 & 2893 & 763 & 454 & -189 \\
\hline Energine & 50 & 50 & 247 & 607 & 335 & 808 & 100 & 11 & -17 \\
\hline Yinxing & 154 & 221 & 32 & 1048 & 926 & 702 & 87 & 50 & 32 \\
\hline HEwind & 166 & 153 & 110 & 753 & 571 & 246 & 131 & 107 & 18 \\
\hline \multicolumn{10}{|c|}{ Global leaders } \\
\hline Vestas & 4057 & 5054 & 6171 & 60,481 & 51,240 & 58,810 & 2709 & -527 & 33 \\
\hline Gamesa & 2405 & 2802 & 2119 & 24,157 & 26,630 & 20,310 & 1040 & 1150 & 179 \\
\hline Suzlon Grp. & 2514 & 3116 & 3190 & 25,056 & 28,250 & 30,802 & 1230 & 495 & -1512 \\
\hline Nordex & 1032 & 779 & 909 & 8809 & 8139 & 8972 & 350 & -261 & -498 \\
\hline
\end{tabular}

Notes:

a Not all annual reports supplied sales figures in MW per reporting year; for Sinovel, Yinxing, HEWind and Suzlon, we report that year's installations.

${ }^{\mathrm{b}}$ Revenue may come from turbine sales but also maintenance, operation, other services, etc.

${ }^{c}$ Profits are earnings before interest and taxes (EBIT); data for Yinxing and HEWind are gross profits, as their annual reports contained no further specific data by

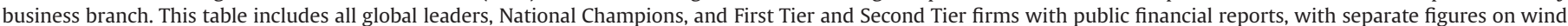
power equipment (for non-pure wind power manufacturers). Sources: company annual reports. 
(Bloomberg, 2012b). Argentina in particular has ambitious plans for wind power development but is having trouble obtaining foreign financing after defaulting on loans in the early 2000s (Bloomberg, 2012a). A number of our interviewees indicated, however, that CDB financing for foreign projects is subject to lengthy approval procedures and in some cases is even more difficult to acquire than local financing. The $\mathrm{CDB}$ is more risk averse in foreign markets, in which it has little experience with renewable energy project financing and less confidence in continued government support, than it is in the domestic market.

Turbine manufacturers can also invest themselves. Sany has invested in wind farms in the US, and Tianrun, Goldwind's subsidiary, has financed wind farms in the US and Australia (company websites). Our interviewees stated that Sinovel and Mingyang have invested in a number of smaller projects that have served as showcases to attract future customers in Eastern Europe.

Lastly, a number of Chinese utilities, including Longyuan, Huaneng, Datang, and China Guangdong Nuclear, have global expansion plans (company websites), which may improve the export prospects for the turbine manufacturers with whom they have connections (Table 5). In global markets, however, these utilities are not driven by government obligations and can be expected to emphasize individual project profitability. Both Longyuan and Datang have signed MoUs with Gamesa for foreign projects (company websites). It is unclear whether preferred supplier relationships will hold up in global expansion projects. With the bulk of global expansion projects still being negotiated, it is too soon to comment on the probable outcomes with much certainty.

\subsection{Creation of legitimacy}

Historically, the legitimacy of Chinese government support for wind power has stemmed from the need to meet rapidly increasing power demands while minimizing greenhouse gas (GHG) emissions and the impact on air quality (Lewis, 2008; Zhang et al., 2013). Government support has been focused on building a domestic industry to reduce manufacturing costs and create new economic activity (Lewis, 2007; Ru et al., 2012).

Support for global expansion stems from industrial rather than environmental policy. While it is accepted that domestic wind power utilization requires financial support, global expansion ought to increase industrial activity and tax revenue. This implies a stronger requirement for Chinese-brand turbines to compete in terms of qualities demanded in the respective export markets. This may differ for projects in other emerging and developing countries. One interviewee referred to CDB financing for projects in these countries as 'tied aid,' i.e., development aid conditional on the use of Chinese equipment. This aid also has a political component, with projects (planned) in Cuba and Pakistan, for example-countries with historically strong political ties to China (Lewis, 2012; Reuters, 2012).

\section{Synopsis and policy recommendations}

China undeniably plays an important role in global innovation in wind power, now that it ranks first in installations and manufacturing volume. It is difficult to assess Chinese turbine quality accurately because of a lack of public data on operational performance. The presidents of Sinovel and Goldwind, however, have acknowledged a "quality gap with international leaders" and even being "far behind Vestas, GE or Siemens" (CWP 2012 Conference, 2012b). Although many manufacturers have independently developed their latest turbine models, the number of patent applications by Chinese manufacturers remains markedly low. This suggests that the technological development strength of Chinese manufacturers remains moderate in comparison with that of global leaders and also casts doubt on the newness of the technology embedded in the latest Chinese-brand turbine models.

This gap may be an inevitable result of the longer operational experience (in some cases, decades) of the global leaders. The competitive pressure in the domestic market, however, does not strongly induce quality improvements. Domestic turbine users (wind farm developers) are not pressured by policy to perform in terms of power output and are disincentivized to focus on power output by current difficulties in selling power output from wind farms. As a result, domestic market demand is more strongly orientated toward turbine cost than quality. The pressure to innovate is further reduced by the recent trend of increasing integration of developers and manufacturers. There is a clear need for policy to resolve these issues.

Policy can help incentivize turbine quality improvement by improving the outlook for (and profit from) wind power sales. The recent policy push for $\mathrm{kW}$ h-based obligations has been met with resistance from power and grid companies. This resistance may be reduced when current grid bottlenecks are resolved. Keys to achieving this resolution will be both national and provincial planning, including balanced development of wind farms and power line infrastructure; grid flexibility, e.g., more interwoven (provincial) grids; more transport lines between generation and load centers; more local utilization of wind power and more backup capacity in the event of low wind speeds (for more, see e.g., Li et al. (2012), Zhao et al. (2012a). Maintaining a backup of quickly dispatchable generation capacity is costly. Hydropower can be used for this purpose at moderate cost but is scarce in the wind-rich north of China (CEPP, 2013). The cost associated with balancing the intermittency of wind power can be reduced by increasing the accuracy of wind speed forecasts (Delarue et al., 2009). China's renewable energy law has been amended to clarify responsibility for grid infrastructure investment and to raise support for additional costs associated with the grid infrastructure of remote wind farms, but it remains unclear who is responsible for ensuring sufficient backup capacity and forecasting accuracy (National People's Congress (NPC), 2009). For the latter, Chinese officials could build on the experience of India, which is currently experimenting with obligatory short-term forecasting of power output from wind farms (Bloomberg, 2013).

Policy should further ensure open competition in the turbine market. Pressure to innovate will only exist if turbine manufacturers compete on equal terms in turbine tenders. It is therefore important to regulate connections between wind farm developers and turbine manufacturers. This regulation can be accomplished by introducing percentage quotas for installations with turbines from such preferred suppliers. Policy makers may also seek to regulate bid evaluation criteria, i.e., to place more value on power production rather than simply on turbine cost. Oversight over winning bid selection should also be improved, as a number of our interviewees indicated that developers did not always strictly follow their own bid evaluation criteria in choosing suppliers. Manufacturers who were not selected chose not to litigate to maintain their good standing in future tenders from these developers.

Any policy adjustment will take a considerable amount of time before it affects innovation noticeably. Chinese wind turbine manufacturers do not yet appear to have the innovative strength to compete with global leaders in the most established export markets in the near future. The quest for foreign market share is also poorly timed, as these markets are currently experiencing a downturn as well. Emerging economy markets may be more 
accepting of lower-cost, lower-quality turbines. The forecasted size of these markets is limited, however. Chinese manufacturers' cost advantage will also be reduced by the costs of transport to distant markets. Furthermore, a number of emerging economy markets have introduced local content requirements (Global Wind Energy Council (GWEC), 2013), which are likely to further erode any cost advantage that Chinese manufacturers may have over global competitors.

\section{Concluding remarks}

Our results support Porter's (1990) hypothesis that innovation requires strong, open market competition and customers with discerning quality demands. The lack of such market conditions in China is currently reducing Chinese manufacturers' prospects of developing technological leadership and a strong presence in export markets. In comparison with users in more advanced markets, domestic users are overly focused on turbine cost and focus little attention on turbine quality.

Cost reductions do matter; they are an integral part of technological development, as witnessed by 'learning curves' that have previously been used to gauge technological maturity. Such learning curves do not make much sense, however, if the products compared differ in technological quality.

China's domestic wind turbine market is not functioning as a springboard to global market dominance. Rather, Chinese turbine manufacturers are faced with the difficulty of catering to the product quality demands of global market customers without having a domestic market that provides the level of revenue or the development and testing environment required to do so.

However, the turbine market is not entirely commoditized. Turbine purchases are connected to project financing, which may be obtained from the China Development Bank, Chinese utilities that seek global expansion, and turbine manufacturers themselves. This implies that Fagerberg's (1995) and Porter's (1990) assumption that technological leadership is a precondition for the development of export markets may not be entirely applicable to the current global wind turbine market.

\section{Acknowledgements}

This study was supported by the International Scientific Cooperation Program with Grant No. 2012DFA91150, and the Chinese Academy of Sciences under Grant No. KZZD-EW-TZ-12. Jorrit Gosens is the holder of a Foreign Student Scholarship from the Graduate University of the Chinese Academy of Sciences. We would like to thank the editors and reviewers for their valuable comments and suggestions. The authors would also like to thank Lars Coenen, who provided helpful comments on the manuscript.

\section{Appendix A. Wind turbine industry details: Global leaders and Chinese manufacturers}

\begin{tabular}{|c|c|c|c|c|c|c|}
\hline \multirow[t]{2}{*}{ Name } & \multicolumn{4}{|c|}{ Installations (MW) (2011) } & \multirow[t]{2}{*}{ Est. } & \multirow[t]{2}{*}{ Notes } \\
\hline & Global, cum. & China, cum. & China, annual & Exports (\%) & & \\
\hline \multicolumn{7}{|c|}{ Global leaders; included in 2011 top 15} \\
\hline Vestas & 49,332 & 3565 & 662 & 97.5 & 1979 & $\begin{array}{l}\text { Danish. Global market leader since the } \\
\text { 1980s }\end{array}$ \\
\hline Gamesa & 24,143 & 2966 & 362 & 87.0 & 1994 & $\begin{array}{l}\text { Spanish. Started operations on the basis of } \\
\text { a design license from Vestas }\end{array}$ \\
\hline GE & $?$ & 1455 & 408 & 36.7 & 1980 & $\begin{array}{l}\text { American. Predecessor Zond est. 1980. GE } \\
\text { now active in China as a JV with Harbin } \\
\text { Power Eq. }\end{array}$ \\
\hline Suzlon Grp. & 20,000 & 1.101 & 96 & 63.1 & 1995 & $\begin{array}{l}\text { Indian Suzlon acquired German RE-Power, } \\
\text { which was active in China as JV RE-Power } \\
\text { North }\end{array}$ \\
\hline Siemens & 13,700 & 86 & 48 & 97.7 & 1980 & $\begin{array}{l}\text { Germany's Siemens wind division can be } \\
\text { traced back to Danish company Bonus, est. } \\
1980\end{array}$ \\
\hline Enercon & 28,000 & 0 & 0 & 48.1 & 1983 & $\begin{array}{l}\text { German. Not active in China. Not active in } \\
\text { the US after patent litigation with GE }\end{array}$ \\
\hline Nordex & 7543 & 573 & 50 & 92.0 & 1985 & $\begin{array}{l}\text { Danish. Active in China as the JV Nordex- } \\
\text { Yinchuan }\end{array}$ \\
\hline \multirow[t]{2}{*}{ Name } & \multicolumn{3}{|c|}{ Installations (MW) (2011) } & Est. & Notes & \\
\hline & China, cum. & China, annual & Exports & & & \\
\hline
\end{tabular}

National Champions: more than 5 GW of installations

$\begin{array}{llll}\text { Sinovel } & 12,877 & 2939 & \text { None }\end{array}$

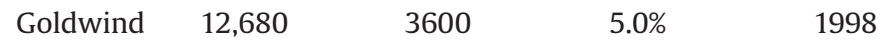

SOE, pure wind power manufacturer. Subsidiary of Dalian Heavy Industry

SOE, pure wind power manufacturer. Goldwind's predecessor Xinjiang Wind Energy Co., a widn farm developer, was established in 1988. 


\begin{tabular}{|c|c|c|c|c|}
\hline Dongfang & 6816 & 946 & None & 2004 \\
\hline $\begin{array}{l}\text { United } \\
\text { Power }\end{array}$ & 5252 & 2847 & $0.3 \%$ & 2007 \\
\hline \multicolumn{5}{|c|}{ First Tier manufacturers: 1 to $3 \mathrm{GW}$ of installations } \\
\hline Mingyang & 3123 & 1178 & None & 2006 \\
\hline XEMC & 1801 & 713 & $0.7 \%$ & 2006 \\
\hline $\begin{array}{l}\text { Shanghai } \\
\text { Electric }\end{array}$ & 1782 & 708 & None & 2006 \\
\hline $\begin{array}{l}\text { China } \\
\text { Creative }\end{array}$ & 1349 & 626 & None & 2006 \\
\hline Windey & 1098 & 375 & None & 2 \\
\hline
\end{tabular}

$\begin{array}{lcccc}\begin{array}{l}\text { Second Tier manufacturers: } \\ \text { CSR }\end{array} & \mathbf{3 0 0} \mathbf{~ M W} \text { to } \mathbf{1} \text { GW of installations } \\ \begin{array}{l}\text { Zhuzhou } \\ \text { CSIC }\end{array} & 877 & 451 & \text { None } & 2008 \\ \begin{array}{l}\text { Haizhuang } \\ \text { Envision }\end{array} & 747 & 396 & 1.0 \% & 2006 \\ \begin{array}{l}\text { Yinxing } \\ \text { HEwind }\end{array} & 473 & 348 & \text { None } & 2008 \\ \text { HEs } & 405 & 221 & \text { None } & 2007 \\ \text { Energine } & 380 & 151 & 1.0 \% & 2005 \\ \end{array}$

Sany

323

180

$6.3 \%$

2008
SOE, power generation equipment and heavy industry group SOE, pure wind power manufacturer. Subsidiary of Guodian, one of China's largest utilities

Privately owned, power generation equipment group SOE, power generation equipment group SOE, power generation equipment group

Privately owned, pure wind power manufacturer. Spin-off from Shenyang Univ. of Technology

SOE, pure wind power manufacturer. Spin-off from Zhejiang Inst. of Electro-mechanics

SOE, large industrial conglomerate, core product is locomotives

SOE, large industrial conglomerate, main activity is shipbuilding

Privately owned, pure wind power manufacturer SOE, provincial utility and power generation equipment manufacturer

SOE, large industrial conglomerate (HEAG), core product is electrical apparatus

SOE, subsidiary of China Aerospace S\&T Corporation

(CASC), which previously was in a JV with Spanish

Acciona. Energine produces wind turbines and other rare earth applications

SOE, manufacturer of heavy machinery

\section{Third Tier manufacturers: less than 300 MW}

Annual additions for these firms have been 50 MW or less. This is considered very small in China, as wind farms are mostly developed in $50 \mathrm{MW}$ sections, with a single equipment supplier. This group contains around 50 firms, about half of them state owned and about half private firms. The bulk of these was established 2008 or later
- Beizhong • XJ Group
- Tianwei
- New United • Changxing
(167 MW) (150 MW)
$\begin{array}{ll}\text { (200 MW) } & (192 \mathrm{MW}) \\ \text { Huide } & \bullet \text { Ruihao }\end{array}$
(189 MW)
- Guoce (GC) • Hanwei
(84 MW)
(45 MW)
- Jiuhe
(14)
$(14 \mathrm{MW})$
- Sharpower (80 MW)
- 43 others (122 MW)

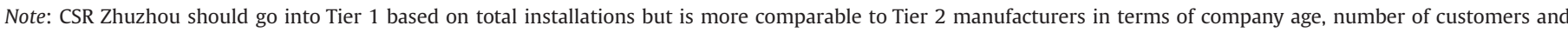

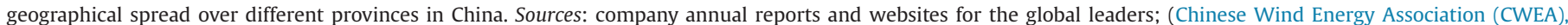
2012a, 2012c; China Wind Energy Equipment Association (CWEEA), 2010) for Chinese manufacturers.

\section{References}

Abramovitz, M., 1986. Catching up, forging ahead, and falling behind. J. Econ. Hist. 46, 385-486.

Accenture, 2012. China's Wind-Power Industry: The Insider's View.

Ackermann, T., Söder, L., 2002. An overview of wind energy-status 2002. Renewable Sustainable Energy Rev. 6, 67-127.

AMSC, 2011. AMSC Filing Criminal and Civil Complaints Against Sinovel, Company Announcement Dated Sep. 14th 2011.

Barradale, M.J., 2010. Impact of public policy uncertainty on renewable energy investment: wind power and the production tax credit. Energy Policy 38, 7698-7709.

Bayer, P., Dolan, L., Urpelainen, J., 2013. Global patterns of renewable energy innovation, 1990-2009. Energy Sustainable Dev. 17, 288-295.

Beise, M., 2005. Lead markets, innovation differentials and growth. Int. Econ. Econ. Policy 1, 305-328.

Beise, M., Rennings, K., 2005. Lead markets and regulation: a framework for analyzing the international diffusion of environmental innovations. Ecol. Econ. $52,5-17$.

Bergek, A., Jacobsson, S., Carlsson, B., Lindmark, S., Rickne, A., 2008. Analyzing the functional dynamics of technological innovation systems: a scheme of analysis. Res. Policy 37, 407-429.

Berkhout, F., Verbong, G., Wieczorek, A.J., Raven, R., Lebel, L., Bai, X., 2010. Sustainability experiments in Asia: innovations shaping alternative development pathways? Environ. Sci. Policy 13, 261-271.
Binz, C., Truffer, B., Li, L., Shi, Y., Lu, Y., 2012. Conceptualizing leapfrogging with spatially coupled innovation systems: the case of onsite wastewater treatment in China. Technol. Forecast. Soc. Change 79, 155-171.

Bloomberg, 2012a. Argentina Plans Biggest Wind Project with Loan from China, Jul. 6 th 2012.

Bloomberg, 2012b. China Grabs Share in Latin America Wind with Cheap Loans, Nov. 21st 2012.

Bloomberg, 2013. Wind Forecast Order Jeopardizes Industry, Tata Power Says, July 16th, 2013.

BTM Consult, 2012. Oppoprtunities and challenges in the global turbine manufacturing industry. In: Presentation by Mr. Zhao Feng of BTM Consult at the China Wind Power 2012 Conference, 16 November 2012, Beijing.

CEC (China Electricity Council), 2012. Renewable Power Quota Regulation (draft).

CEC (China Electricity Council), 2013. Power Industry Monitoring Report 2012 (In Chinese).

CEPP, 2013. China Electric Power Yearbook, Several Years Used. China Electric Power Press, Beijing.

China Wind Power Net, 2013. Selected Articles from fenglifadian.com, online Wind Industry News Site (In Chinese).

CRESP, 2012. China Renewable Scale-up Programme, Fact Sheet Overview at $\langle$ cresp org.cn/english/Fact_Sheet.asp 〉, Last Accessed Sept. 28th 2012.

Chinese Wind Energy Association (CWEA), 2012a. China Wind Power Industry Map, Several Years Used (In Chinese).

Chinese Wind Energy Association (CWEA), 2012b. China Wind Power Outlook 2012. 
Chinese Wind Energy Association (CWEA), 2012c. Wind Power Statistics China (Several Years Used) (In Chinese).

Chinese Wind Energy Association (CWEA), 2013. Wind Energy Magazine (In Chinese) Several Editions Used.

China Wind Energy Equipment Association (CWEEA), 2010. Basic Information of the Wind Power Equipment Industry, 2009 Update (In Chinese).

CWP 2012 Conference, 2012a. Entrepreneurs forum for developers, attended by high level management from Longyuan, Datang, Huaneng, CWP, CECEP, CGN, Tianrun, Mainstream Energy, State Grid Energy Research Institute and UK Trade \& Investment. In: Wind Power 2012 Conference, Nov. 15-17, 2012, Beijing.

CWP 2012 Conference, 2012b. Entrepreneurs forum for turbine manufacturers, attended by high level management from Goldwind, Sinovel, United Power, Mingyang, Siemens China, GE Wind power China, Gamesa China and Nordex China. In: Wind Power 2012 Conference, Nov. 15-17, 2012, Beijing.

De Fuentes, C., Chaminade, C., 2012. Who are the world leaders in innovation? The changing role of firms from emerging economies. In: Paper Presented at the DRUID 2012 Conference, June 2012, Copenhagen, Denmark.

Delarue, E.D., Luickx, P.J., D'haeseleer, W.D., 2009. The actual effect of wind power on overall electricity generation costs and $\mathrm{CO}_{2}$ emissions. Energy Convers. Manage. 50, 1450-1456.

US Energy Information Administration (EIA), 2012. Wind Energy Tax Credit Set to Expire at the End of 2012 (online news item).

European Patent Office (EPO), 2012. Espace Net Global Patent Database.

Energy Research Institute (ERI), S.G., 2012. New Energy Industry Development Trends Report (In Chinese).

European Wind Energy Association (EWEA), 2011a. Pure Power-Wind Energy Targets for 2020 and 2030.

European Wind Energy Association (EWEA), 2011b. Upwind: Design Limits and Solutions for Very Large Turbines.

European Wind Energy Association (EWEA), 2012a. The European Offshore Wind Industry-Key Trends and Statistics 1st half 2012.

European Wind Energy Association (EWEA), 2012b. Wind Energy and EU Climate Policy-Achieving 30\% Lower Emissions by 2020.

European Wind Energy Association (EWEA), 2012c. Wind in Power-2011 European Statistics.

European Wind Energy Association (EWEA), 2013. Wind in Power-2012 European Statistics.

Faber, J., Hesen, A.B., 2004. Innovation capabilities of European nations: crossnational analyses of patents and sales of product innovations. Res. Policy 33 193-207.

Fagerberg, J., 1995. User-producer interaction, learning and comparative advantage. Cambridge J. Econ. 19, 243-256.

Financial Times, 2012. Desenvix Drops Lawsuit Against Sinovel; Aug. 9th 2012.

Freeman, C., Soete, L., 1997. The Economics of Industrial Innovation, third ed. Pinter, London.

Fu, X., Pietrobelli, C., Soete, L., 2011. The role of Foreign technology and indigenous innovation in the emerging economies: technological change and catching-up. World Dev. 39, 1204-1212.

Goldwind, 2012. 2012 Half Year Report (In Chinese).

Gosens, J., Lu, Y., 2013. From lagging to leading? Technological innovation systems in emerging economies and the case of Chinese wind power. Energy Policy 60, 234-250.

Global Wind Energy Council (GWEC), 2007. China Wind Power Report 2007.

Global Wind Energy Council (GWEC), 2012a. China Wind Energy Development Update 2012

Global Wind Energy Council (GWEC), 2012b. Global Wind Energy Outlook (Severa Years Used).

Global Wind Energy Council (GWEC), 2012c. Global Wind Report (Several Years Used).

Global Wind Energy Council (GWEC), 2013. Global Wind Report, Annual Market Update 2012

Han, J., Mol, A.P.J., Lu, Y., Zhang, L., 2009. Onshore wind power development in China: challenges behind a successful story. Energy Policy 37, 2941-2951.

Hekkert, M.P., Suurs, R.A.A., Negro, S.O., Kuhlmann, S., Smits, R.E.H.M., 2007 Functions of innovation systems: a new approach for analysing technological change. Technol. Forecast. Soc. Change 74, 413-432.

Hu, X., 2013. Renewable Electricity Quotas will be Transferred to Local Governments. 21st Century Business Herald. (Feb. 28th, 2013 (In Chinese).

Hu, Z., Wang, J., Byrne, J., Kurdgelashvili, L., 2013. Review of wind power tariff policies in China. Energy Policy 53, 41-50.

IEA Wind, 2012. Annual Report (Several Years Used).

IEA/ERI, 2012. China Wind Energy Development Roadmap 2050. Report by the International Energy Agency and the Energy Research Institute (ERI) of the National Development and Reform Commission (NDRC) of P.R. China.

IHS Emerging Energy Research (IHS-EER), 2012. Global Wind Energy Market Update 2011.

Johanson, J., Vahle, J.E., 1977. The internationalisation process of the firm-a model of knowledge development and increasing foreign market commitments. J. Int. Bus. 8, 22-32.

Kang, J., Yuan, J., Hu, Z., Xu, Y., 2012. Review on wind power development and relevant policies in China during the 11 th Five-Year-Plan period. Renewable Sustainable Energy Rev. 16, 1907-1915.

Kim, L., 1993. National system of industrial inovation: dynamics of capability building in Korea. In: Nelson, R. (Ed.), National Innovation Systems-A Comparative Analysis. Oxfrod University Press, New York, pp. 357-385.

Kim, L., 1997. Imitation to Innovation: The Dynamics of Korea's Technologica Learning. Harvard Business School Press, Boston, MA.
Lema, A., Ruby, K., 2007. Between fragmented authoritarianism and policy coordination: creating a Chinese market for wind energy. Energy Policy 35, 3879-3890.

Lema, R., Lema, A., 2012. Technology transfer? The rise of China and India in green technology sectors. Innov. Dev. 2, 23-44.

Levi, M.A., Economy, E.C., O’Neil, S.K., Segal, A., 2010. Energy Innovation; Driving Technology Competition and Cooperation Among the U.S., China, India, and Brazil. Report of the Council on Foreign Relations.

Lewis, J.I., 2007. Technology acquisition and innovation in the developing world: wind turbine development in China and India. Stud. Comp. Int. Dev. 42 $208-232$.

Lewis, J.I., 2008. China's strategic priorities in international climate change negotiations. Wash. Q. 31, 155-174.

Lewis, J.I., 2012. Green Innovation in China-China's Wind Power Industry and The Global Transition to a Low-Carbon Economy. Columbia University Press, New York.

Lewis, J.I., Wiser, R.H., 2007. Fostering a renewable energy technology industry: an international comparison of wind industry policy support mechanisms. Energy Policy 35, 1844-1857.

Li, H., Meng, L., Wang, Q., Zhou, L.-A., 2008. Political connections, financing and firm performance: evidence from Chinese private firms. J. Dev. Econ. 87, 283-299.

Li, L., Shi, P., Hu, G., 2010. China Wind Power Outlook 2010. Joint Report of GWEC, CREAI and Greenpeace.

Li, X., Hubacek, K., Siu, Y.L., 2012. Wind power in China-dream or reality? Energy 37, 51-60.

Liu, Y., Kokko, A., 2010. Wind power in China: policy and development challenges. Energy Policy 38, 5520-5529.

Lundvall, B.A., Joseph, K.J., Chaminade, C., Vang, J. (Eds.), 2009. Innovation Systems and Developing Countries: Building Domestic Capabilities in a Global Setting. Edward Elgar, Cheltenham and Northampton.

Markard, J., Raven, R., Truffer, B., 2012. Sustainability transitions: an emerging field of research and its prospects. Res. Policy 41, 955-967.

MOFCOM (Zhejiang prov.), 2006. CECIC and Zhejiang Electromechanical Group from JV to Boost Turbine Manufacture Localization.

MOST, 2012a. 12th Five Year Plan: Special Plan for the Development of Wind Power Science and Technology (MOST, 2012, nr. 197) (In Chinese)

MOST, 2012b. 2012 National 863 Programme, Advanced Energy Technology Projects.

MOST, 2012c. 2012 National S\&T Support Programme, Energy Technology Items.

NDRC, 2003. Notice on Concession Project Preparation Management Technical Requirements (NDRC Energy (2003) 1403) (In Chinese).

NDRC, 2007. Medium and Long-Term Development Plan for Renewable Energy (NDRC Energy, 2007, nr. 2174).

NDRC, 2009a. Cancellation of Requirements Concerning Localization Rates of Wind Park Equipment Purchases (NDRC Energy, 2009, nr. 2991).

NDRC, 2009b. Improved Wind Power Pricing Policy (NDRC Price, 2009, nr. 1906).

National Energy Administration (NEA), 2012. 12th Five Year Plan for Renewable Energy (In Chinese).

Nelson, R., Rosenberg, N., 1993. Technical innovation and national systems. In: Nelsen, R. (Ed.), National Innovation Systems: A Comparative Analysis. Oxford University Press, Oxford.

National People's Congress (NPC), 2009. Renewable Energy Law, Amendment of Dec. 26th, 2009 (In Chinese).

People's Daily, 2011. Great Leap Forward for Off-shore Wind: Developers Complain Domestic Turbines are not Reliable (In Chinese), Jun. 17th 2011.

Pew Environment Group, 2012. Who's Winning the Clean Energy Race? Growth. Competition and Opportunity in the World's Largest Economies.

Porter, M., 1990. The Competitive Advantage of Nations. Free Press, Macmillan, New York.

Recharge News, 2012. Mainstream Freezes 1 GW Sinovel Deal Over AMSC Dispute; Nov. 24th 2011.

Reuters, 2012. China Firm in Talks for \$3 bln Pakistan Wind Farm; May 30th 2012.

Roland Berger Market Research, 2004. Study on the Cost of Patenting-Report Prepared for the European Patent Office.

Ru, P., Zhi, Q., Zhang, F., Zhong, X., Li, J., Su, J., 2012. Behind the development of technology: the transition of innovation modes in China's wind turbine manufacturing industry. Energy Policy 43, 58-69.

State Owned Assets Supervision and Administration Comission (SASAC), 2011. Datang and China Creative Hold Strategic Cooperation Ceremony. News Item on sasac.gov.cn (In Chinese)

Sayre, R.J., 2010. Typical End-to-End Costs for Obtaining and Maintaining a US Patent-Report by Modern Times Legal.

Scott, J.T., 1997. Schumpeterian competition and environmental R\&D. Manage. Decis. Econ. 18, 455-469.

Shi, P., 2012. New challenges and opportunities in the wind power industry. In: Presentation by Pengfei Shi, Vice-President of CWEA, at the China Wind Power conference, Nov. 2012.

State Intellectual Property Office (SIPO), 2012. Online Patent Database at $<$ sipo.gov. $\mathrm{cn} / \mathrm{zljs} /\rangle$.

State Planning Commision (SPC), 1997. New Energy Basic Construction Projects: Provisional Decisions (Transport and Energy, 1997, nr. 955) (In Chinese).

State Council of P.R. China, 2009. Opinions on Preventing Industrial Overcapacity and Duplication, and Guiding the Healthy Development of Industry (State Council 2009, nr. 38) (In Chinese).

State Council of P.R. China, 2010. Details on Implementation of the Patent Law of the P.R. China (2010 Amendment). 
State Council of P.R. China, 2012. Opinions on Deepening Technological System Reform and Accelerating the Construction of a National Innovation System.

Totaro \& Associates, 2011. Current and Future Trends in Wind Turbine TechnologyReport Prepared for WIPO.

Truffer, B., 2012. The need for a global perspective on sustainability transitions. Environ. Dev. 3, 182-183.

UNEP/ICTSD/EPO, 2010. Patents and Clean Energy: Bridging the Gap Between Evidence and Policy.

UNIDO, 2010. Climate Innovation Centers-New Way to Foster Climate Technologies in the Developing World?

Wang, Z., Qin, H., Lewis, J.I., 2012. China's wind power industry: policy support, technological achievements, and emerging challenges. Energy Policy 51, 80-88.

Windpower Monthly, 2013a. China's Wind Sector Lost \$1.6 billion in 2012; Jan. 5th 2013.

Windpower Monthly, 2013b. Record Year for US Wind Industry in 2012, Jan. 31st 2013.

Windpower Monthly, 2013c. Sinovel Moves into Project Construction, Apr. 29th 2013.

Wiser, R., Bolinger, M., 2012. 2011 Wind Technologies Market Report, Report for the U.S. Department of Energy.

World Bank, 2011. Global Development Horizons 2011-Multipolarity: The New Global Economy, Washington D.C.

Wu, J., Li, C., 2012. Thoughts on China's wind power equipment tender system (In Chinese). Wind Energy 3, 22-25.
Xinhua News, 2012a. Shanghai Offshore Wind Farm Claims World First. Xinhua News Agency. (Feb. 3rd 2012.)

Xinhua News, 2012b. Troubled Sinovel Wind to Put Workers on Leave, Nov. 20th, 2012

Xu, C., 2011. The fundamental institutions of China's reforms and development. J. Econ. Lit. 49, 1076-1151.

Yang, C.-J., Xuan, X., Jackson, R.B., 2012a. China's coal price disturbances: observations, explanations, and implications for global energy economies. Energy Policy 51, 720-727.

Yang, M., Patiño-Echeverri, D., Yang, F., 2012b. Wind power generation in China: understanding the mismatch between capacity and generation. Renewable Energy 41, 145-151.

Zhang, S., Andrews-Speed, P., Zhao, X., 2013. Political and institutional analysis of the successes and failures of China's wind power policy. Energy Policy 56, $331-340$

Zhang, S., Li, X., 2012. Large scale wind power integration in China: analysis from a policy perspective. Renewable Sustainable Energy Rev. 16, 1110-1115.

Zhao, X., Wang, F., Wang, M., 2012a. Large-scale utilization of wind power in China: obstacles of conflict between market and planning. Energy Policy 48, 222-232.

Zhao, X. Zhang, S. Yang, R. Wang, M., 2012b. Constraints on the effective utilization of wind power in China: an illustration from the northeast China grid. Renewable Sustainable Energy Rev. 16, 4508-4514. 